\title{
Representações visuais da mulher leitora: notas sobre as transmutações de uma prática cultural
}

Fabrício José Nascimento da Silveira

Doutor; Universidade Federal de Minas Gerais

Email: fabrisilveira@gmail.com

\section{Paulo Bernardo Ferreira Vaz}

Doutor; Universidade Federal de Minas Gerais, Universidade

Fundação Mineira de Educação e Cultura

Email: paulobvaz@gmail.com

\section{Resumo}

O trabalho apresenta resultados parciais de uma investigação que busca apreender o lugar simbólico-respresentacional ocupado/destinado às mulheres no âmbito da história da leitura. Para tanto, adota como universo empírico figurações e experiências visuais concebidas por artistas plásticos e fotógrafos no contexto geral da história da arte. Tendo por objeto empírico um vastíssimo conjunto de obras pictóricas e fotográficas, o estudo analisa três momentos específicos nos quais os gestos de leitura empreendidos pelas mulheres e o seu contato com os objetos impressos configuravam-se segundo quadros de sentido amplamente enraizados na esfera cultural, a saber: a mãe zelosa que transmite a seus filhos, por meio da leitura, os preceitos e normas que amparavam a vida religiosa e comunal na Idade Média; as moças sonhadoras do período romântico que fizeram da leitura, tanto pública quanto privada, um recurso de auto-formação individual e emancipador; e, por fim, a leitura como uma prática corriqueira e incorporada ao dia-a-dia das mulheres "modernas", estejam elas em casa ou no espaço coletivo, em momentos de lazer ou em atividades laborais. Ao fim desse percurso, ressalta-se que a leitura é uma prática cultural de apreensão e simbolização do mundo cujos gestos, fazeres e representações assentam-se, em larga medida, nas distintas matrizes de significação que conformam e informam a vida social.

\section{Palavras-chave}

Leitura. História da leitura. Leitura feminina. Representação visual. Imaginário. Objetos impressos. Prática cultural. 


\section{Introdução}

Há livros sobre todo tipo de assuntos, que, há uma geração, nenhuma mulher teria tocado. Há poemas e peças e críticas; há histórias e biografias, livros de viagens e livros de erudição e pesquisa; há até algumas filosofias e livros sobre ciência e economia. E embora os romances predominem, é bem possível que os próprios romances tenham mudado a partir da associação com livros de outra natureza. [...] A leitura e a crítica talvez lhe tenham ampliado mais o alcance, aumentando a sutileza. (WOOLF, 1985, p. 105).

Os apontamentos que se seguem tiveram como marco desencadeador uma experiência estética. Ao visitarmos a mostra World Press Photo 2013, organizada pela Caixa Cultural Brasília entre os meses de julho a agosto daquele ano, uma imagem chamou-nos a atenção dentre as 154 cenas em exposição. Capturada pelo americano Micah Albert, a fotografia tem por cenário o lixão de Dandora, no Quênia, e focaliza uma catadora absorta na leitura de um livro recolhido junto aos muitos resíduos que inundam a paisagem ao seu redor. Sob um céu cinza, cujas nuvens dão sinais de uma iminente a figura feminina, tal qual em uma pintura de Vermeer, atrai o olhar do espectador não só porque o contraste entre luz e sombra a coloca em uma posição de centralidade, mas, sobretudo, em função dos simbolismos que atravessam o gesto por ela empreendido.

O que, no livro aberto em suas mãos, teria mobilizado a jovem africana a interromper o trabalho e dedicar uma fração de seu tempo ao exercício da leitura? Seria o estranhamento por ter se deparado com um livro, artefato de "cultura" e "educação" por natureza, em um lugar onde são despejadas as coisas inúteis e sem valor aparente? Na impossibilidade de se conferir respostas satisfatórias a essas questões, o flagrante de Micah Albert nos impulsionou a refletir sobre a importância social da leitura e as múltiplas representações visuais que instituem a leitura feminina como argumento figurativo e/ou princípio inspirador. 
Figura 1 - Reprodução da fotografia "At the Dandora dump", de Micah Albert (2013)

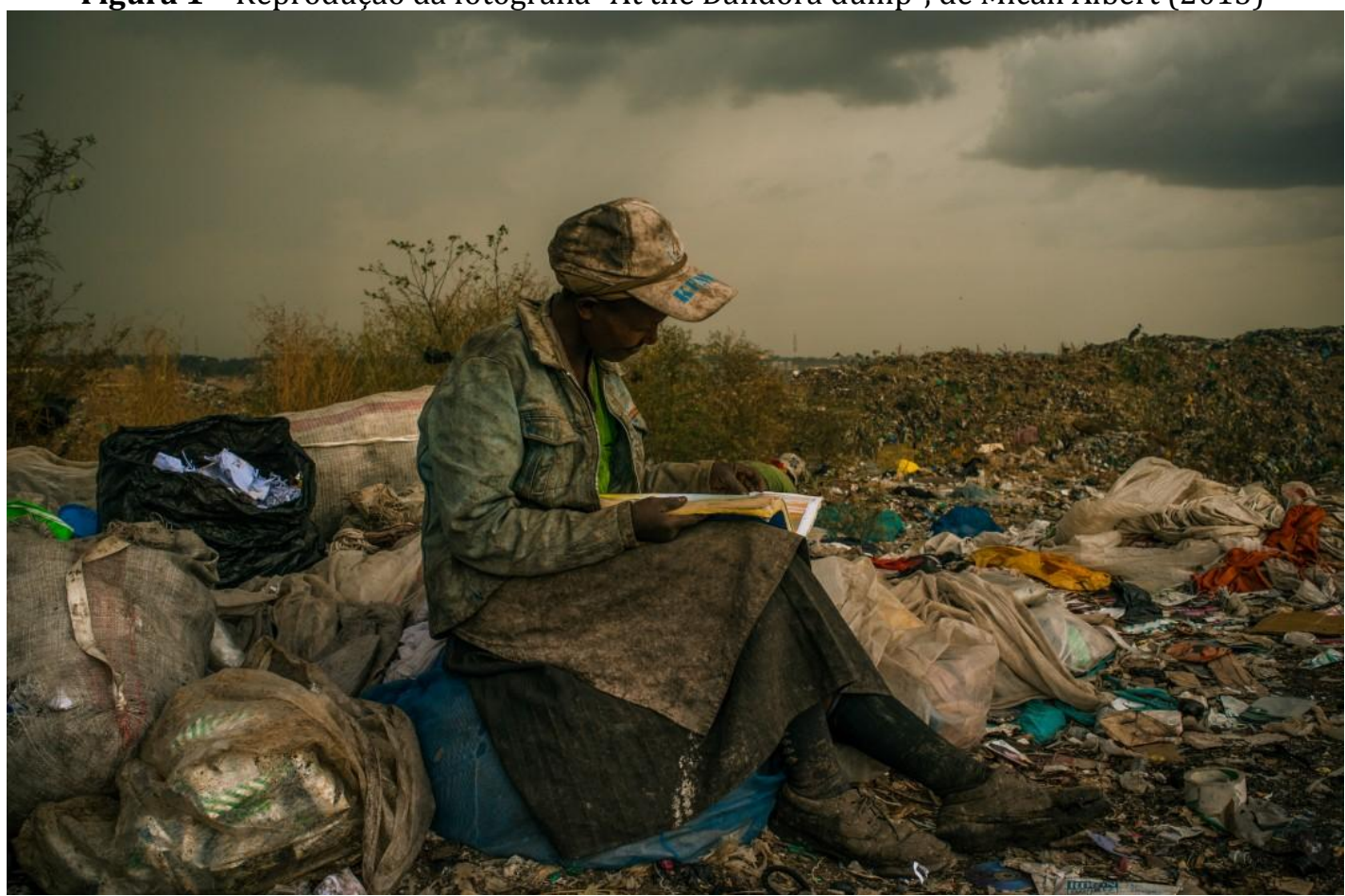

Fonte: Albert (2013).

Através de pesquisa em museus e galerias virtuais, catálogos de exposições e livros de artes e história da leitura, nos deparamos com uma quantidade impressionante de imagens pinturas, gravuras, esculturas, fotografias, etc. - que, em seu conjunto, acenam para inúmeras transformações sofridas por essa prática cultural ao longo de vários séculos, assim como facultam observar mudanças expressivas nos espaços ocupados pelas mulheres no âmbito da história das práticas leitoras.

Mesmo tratando-se de estudo ainda em execução, as 684 imagens coletadas ${ }^{1}$ até aqui nos permitem assinalar três contextos específicos nos quais a presença feminina e suas relações com os objetos de leitura, principalmente o livro, ganham forma, configurando-se segundo quadros de sentido amplamente enraizados na esfera cultural, a saber: a mãe zelosa que transmite a seus filhos os preceitos e normas que amparam a vida religiosa e comunal; as moças sonhadoras que fazem da leitura, tanto pública quanto privada, de romances, um recurso de entretenimento e auto-formação individual; e, em um enquadramento mais contemporâneo, o gesto leitor como uma prática corriqueira e

\footnotetext{
${ }^{1}$ A mais antiga delas é de um afresco de Pompeia que retrata uma mulher examinando um rolo de papiro e a mais recente o quadro intitulado "Hadewich", um óleo sobre tela do pintor holandês Ralf Heynen datado de 2013.
} 
incorporada ao dia-a-dia das mulheres, estejam elas em casa ou no espaço coletivo, em situações de lazer ou em atividades laborais, tal como no retrato do lixão de Dandora.

Atentando para tais índices enunciativos, mas sem ostentar a pretensão de constituir uma história das mulheres ou de passar em revista os estudos sobre as representações da atividade leitora, o texto que se segue estrutura-se em duas partes bem demarcadas. A primeira, de cunho eminentemente teórico, recorre aos trabalhos de Michel de Certeau para responder à seguinte pergunta: Por que a leitura se define como uma prática cultural? Na segunda parte, analisamos as distintas matrizes de significação que perpassam as figurações visuais erigidas com vistas a encenar a prática da leitura feminina em três momentos históricos determinados: ao final da Idade Média; na transição dos séculos XVIII para o XIX; e na contemporaneidade, notadamente a partir dos anos de 1950.

Trilhando esse percurso e adotando por prerrogativa que as imagens - assim como os relatos e acontecimentos - nos informam, esperamos poder evidenciar que a recorrência temática e iconográfica que conforma as representações visuais da leitura feminina em cada um dos períodos acima delimitados se posta como dispositivo interpretativo capaz de desvelar os jogos de poderes, as normas e os juízos de valores que assinalam funções, expectativas e lugares definidos tanto para a leitura em si, quanto para as mulheres que a praticam. Comecemos, pois, pelo trabalho de lapidação conceitual.

\section{A leitura e sua polissemia cultural: as contribuições de Michel de Certeau}

No $12^{\circ}$ capítulo do seu $A$ invenção do cotidiano, Michel de Certeau estabelece a seguinte ponderação: “Ler é uma operação de caça." (CERTEAU, 1994, p.259). Em seu sentido mais objetivo, tal proposição assinala que a atividade leitora encerra em si mesma um conjunto de saberes, fazeres e ações, de avanços e recuos no texto cujo intuito não é, necessariamente, desvelar seu significado original, mas, antes, construí-lo, ordená-lo de acordo com códigos de percepções e interesses que escapam tanto à estagnação temporal quanto às implicações linguísticas.

Não por acaso, ao enquadrar a leitura no rol das práticas culturais, o historiador acaba por ressaltar que essa atividade não se configura como um ato natural, mas sim como uma série de gestos históricos, políticos e socialmente estruturados. Extrapolando uma conceitualização meramente denotativa, Certeau define o gesto leitor como uma arte investigativa que, nas palavras de CHARTIER e HÉBRARD (1998, p.32), 
[...] quase não deixa traços visíveis nem garantias contra a usura do tempo, mas ação produtora que, em cada um dos seus encaminhamentos e de fazeres, ao mesmo tempo alteram e conferem existência ao texto.

Razão pela qual não deve ser pensada como algo neutro em relação ao mundo, mas, sim, como ato que produz, na sua própria dinâmica, caminhos diferenciados para uma ação social concreta em virtude da diversidade das necessidades e dos interesses de cada agente que lhe confere uma feição e um valor. Em outros termos: mais que um ato hermenêutico ou uma exegese erudita, a leitura se converte em trabalho do pensamento, em recurso de apropriação do mundo, em movimento de permanente ressignificação da realidade.

De fato, enquanto atividade interpretativa e de produção de sentido, a leitura não se posta como um processo de recepção delimitado por conteúdos objetivos ou como ato passivo de sujeição ao texto. Todo leitor, dessa forma, caça em terras alheias,

[...] demarca com os olhos, com o dedo, com o franzir das sobrancelhas, com o sorriso, seus caminhos em busca do sentido. Sob a contingência, sem dúvida, e no espaço próprio do texto, ele elabora - como quer ou como pode - sua leitura do texto: um novo texto. (CHARTIER; HÉBRARD, 1998, p. 33).

A leitura se dá a ver, portanto, como um processo de construção cultural e histórica que se efetiva a partir da mescla entre as condições materiais destinadas à sua produção e circulação, com a subjetividade e o lugar em que cada leitor se encontra no momento de executá-la. Toda leitura é, então, um processo voluntário da inteligência por meio do qual produzimos e sobrecodificamos sentidos, impressões e significados.

No entanto, mesmo ligando-se à inteligência, a leitura não se define como uma operação intelectual abstrata: ela é também o uso do corpo, uma inscrição dentro de um espaço histórico-temporal e uma relação dos leitores consigo mesmos e com os outros. Não por acaso, “[...] ler tem a ver com a liberdade de ir e vir, com a possibilidade de entrar à vontade em um outro mundo e dele sair". (PETIT, 2009, p.92). Indo mais além e evocando as palavras do próprio Certeau:

A atividade leitora apresenta, ao contrário, todos os traços de uma produção silenciosa: flutuação através da página, metamorfose do texto pelo olho que viaja, improvisação e expectação de significados induzidos de certas palavras, intersecções de espaços escritos, dança efêmera. [...] Ele [o leitor] insinua as astúcias do prazer e de uma reaproximação no texto do outro, aí vai à caça, ali é transportado, ali se faz plural como os ruídos do corpo. Astúcia, metáfora, combinatória, esta produção é igualmente uma "invenção" da memória. Faz das palavras as soluções de histórias mudas. A fina película do escrito se torna um remover de camadas, um jogo de espaços. Um mundo diferente (o do leitor) se introduz no lugar do autor. (CERTEAU, 1994, v.1, p.49). 
Nenhum leitor é confrontado, pois, com textos abstratos, ideais ou desvinculados de uma materialidade espaço-temporal. Ao contrário, eles manipulam objetos, ouvem palavras cujas modalidades governam a leitura e a escrita. Fazendo isso, comandam os possíveis movimentos de compreensão e de apropriação do texto, da mesma forma como ressaltam que “[...] toda história das práticas de leitura é, portanto, necessariamente uma história dos objetos escritos e das palavras leitoras." (CAVALLO; CHARTIER, 2002, v.1, p. 6). Indícios que corroboram a tese de que não existe nada simultaneamente mais real e mais ilusório do que o ato de ler, por quê?

Primeiramente, em um sentido bastante simples, viver é mais fácil para aqueles que sabem ler, não somente as informações, os manuais de instrução, as receitas médicas, os jornais e as cédulas de voto, mas também a literatura. Além disso, supôs-se por muito tempo que a cultura literária tornasse o homem melhor e lhe desse uma vida melhor: com a literatura, o concreto se substitui ao abstrato e o exemplo à experiência para inspirar as máximas gerais ou, ao menos, uma conduta em conformidade com tais máximas. [...] A literatura, instrumento de justiça e de tolerância, e a leitura, experiência de autonomia, contribuem para a liberdade e para a responsabilidade do indivíduo. (COMPAGNON, 2009, p. 29-35).

Isso se dá porque, na concepção de Michel de Certeau (1994), o leitor é um sujeito autônomo, capaz de construir sentidos e imprimir marcas interpretativas no texto que sobrecodifica. De dissecar o signo e de distender seus limites de compreensão. De subverter o texto, de torná-lo móvel, intercambiável. De deslizar sua fantasia, seus desejos e angústias entre as linhas e sentenças formuladas por um autor qualquer.

Longe de serem escritores, fundadores de um lugar próprio, herdeiros dos servos de antigamente, mas agora trabalhando no solo da linguagem, cavadores de poços e construtores de casas, os leitores são viajantes; circulam em terras alheias, nômades caçando por conta própria através dos campos que não escreveram. A escritura acumula, estoca, resiste ao tempo pelo estabelecimento de um lugar e multiplica sua produção pelo expansionismo da reprodução. A leitura não tem garantias contra o desgaste do tempo (a gente se esquece e esquece), ela não conserva, ou conserva mal a sua posse, e cada um dos lugares por onde ela passa é repetição do paraíso perdido. [...] Com efeito, a leitura não tem lugar. (CERTEAU, 1994, v. 1, p. 269-270).

Como a leitura não tem lugar, todo leitor constitui-se como uma figura histórica que respeita a historicidade do signo que lê, mas que promove, concomitantemente, uma ruptura com as leituras feitas até então, empreendendo sua própria interpretação, imprimindo sua marca pessoal no universo de possibilidades de significação que lhe é apresentado. Nestes termos, ele dispõe do poder de desvelar uma verdade que não seja transparente, mas 
latente, potencialmente presente, escondida fora da consciência, imanente, singular e, até aí, inexprimível. Ler é, pois, experimentar possíveis.

Talvez por tais razões o ato de ler inspire e prefigure um rico panorama representacional cujo conjunto acaba por acenar para construções simbólicas, históricas e culturais notadamente marcadas por seu caráter polissêmico. Eis o que pretendemos demonstrar aqui voltando nosso olhar para as inúmeras representações visuais que se reportam às práticas de leitura feminina. Para tanto, conforme já assinalado, serão analisadas na seção seguinte imagens que fazem referência a três momentos específicos da história da leitura. Tal como formulado, esse exercício analítico defenderá a tese de que, para além de uma inspiração estética, as imagens aqui apresentadas apontam para dimensões simbólicas que extrapolam o gesto criativo em si, posto sinalizarem profundas transformações tanto no que se refere à forma como a leitura é praticada pelo público feminino, quanto ao lugar a elas dispensado no âmbito da cultura do impresso.

\section{As transfigurações de uma prática cultural: incursões através das representações visuais da mulher leitora}

O que nos mostra, em termos de apreensão de certos panoramas simbólicos, as representações visuais da mulher leitora? Adotando por premissa que a leitura é uma pratica cultural e que a mesma se exibe de modos diferenciados nos tempos e espaços em que é executada, a presente seção apresenta e analisa um conjunto de imagens no qual os gestos de leitura empreendidos pelas mulheres mostram-se notadamente atravessado por quadros de sentidos e referencias valorativas formuladas a partir da esfera cultural, a saber: a mãe zelosa que transmite a seus filhos, por meio da leitura, os preceitos e normas que amparavam a vida religiosa e comunal na Idade Média; as moças sonhadoras do período romântico que fizeram da leitura, tanto pública quanto privada, um recurso de auto-formação individual e emancipador; e, por fim, a leitura como uma prática corriqueira e incorporada ao dia-a-dia das mulheres "modernas", estejam elas em casa ou no espaço coletivo, em momentos de lazer ou em atividades laborais.

Percurso que nos permitirá evidenciar, ao final de nossas discussões, porque pensamos a leitura como uma prática cultural de apreensão e simbolização do mundo cujos gestos, fazeres e representações assentam-se, em larga medida, nas distintas matrizes de significação que conformam e informam a vida social. 


\title{
3.1 Finais da Idade Média: a leitura como ato devocional
}

Segundo Assunción Bernárdez (2007), existem quatro representações que são recorrentemente acionadas para se fazer menção às práticas de leitura exercidas pelas mulheres no contexto do mundo medieval. São elas: as imagens da Virgem da Anunciação; as pinturas de santas; a arte funerária e as figurações de Sant'Anna ao lado da Virgem e do Menino Jesus. Conjunto iconográfico que tinha por objetivo primário aproximar as leitoras de um modelo de comportamento desejado para as mulheres burguesas, sobretudo as mães de família.

Os objetos lidos eram, quase que exclusivamente, textos religiosos (bíblias, livros de horas, saltérios, entre outros), embora houvesse também obras de cavalaria e algumas de ficção. Os volumes eram encadernados em materiais luxuosos, mas também havia aqueles confeccionados com matéria-prima bem barata. A leitura normalmente era praticada em locais isolados e feita de maneira silenciosa, quase em estado de oração, o que revela uma concepção de mulher etérea, idealizada, essencializada e solitária. Além disso, e tendo por referência a realidade histórico-contextual das mulheres medievais, é possível supor:

\begin{abstract}
Que havia muitas mulheres que aprendiam a ler sozinhas, como um prolongamento de suas tarefas cotidianas e das relações que se estabeleciam entre as mulheres de uma mesma família: mulheres adultas que ensinavam às filhas uma série de tarefas domésticas e a preparação para serem futuras esposas, entre a qual se incluía um certo adestramento pela leitura, e que, conforme a classe burguesa vai emergindo em toda a Europa, a alfabetização deixa de ser um adorno nobiliário mais ou menos desejável para as filhas, para converter-se em uma necessidade e parte do adestramento de uma esposa que colaborará com o marido na administração do negócio familiar². (BERNÁRDEZ, 2007, p.76, tradução nossa).
\end{abstract}

Não por acaso, em termos de recorrência, a figura mais acionada para se fazer menção à leitura praticada pelas mulheres nesse período é a da Virgem da Anunciação. Esteja sozinha ou acompanhada pelo anjo e, por vezes, do Espírito Santo, a jovem Maria é pintada como uma nobre dama que empreende sua leitura em um ambiente tranquilo e solitário. Ao se postar como um exercício introspectivo a ser executado intensiva e não extensivamente, o arquétipo da Anunciação enseja um padrão de leitura altamente moralizante e destituído de qualquer aproximação com elementos de fruição estética, prazeres mundanos ou mesmo de

\footnotetext{
2 [...] que hubiera muchas mujeres que aprendiesen solamente a leer como una prolongación de sus tareas cotidianas, de las relaciones que se establecían entre las mujeres de una misma familia: mujeres adultas que enseñaban a niñas una serie de tareas domésticas y una preparación para ser futuras esposas, en las que se incluía un cierto adiestramiento en la lectura, ya que, conforme va emergiendo la clase burguesa en toda Europa, la alfabetización va dejando de ser una especie de adorno nobiliario más o menos deseable para las hijas, para convertirse en una necesidad y parte del adiestramiento de una esposa que colaborará con el marido en la administración del negocio familiar.
} 
atividades vinculadas à produção de conhecimentos pautada por uma lógica mais racionalizada, essa última um domínio tipicamente masculino.

Emergindo como um contraponto à figura de Eva, aquela que se deixou seduzir pela serpente e está na origem da disseminação do mal, o culto à Virgem começou a se desenvolver no século XI, ganhando impulso definitivo em meados do século XII com o florescimento de catedrais e grandes poemas dedicados à consagração de Maria. Enquanto modelo a ser imitado por todas as mulheres, a "Ave" da Anunciação encarna nela mesma o imaginário de que uma vida santa só poderia ser experienciada através de atos de contrição e obediência piedosa. Nesses termos, as representações da Anunciata são executadas, quase todas elas, tendo como principal elemento figurativo uma bela jovem cujos joelhos estão prostrados e as mãos voltadas para o céu ou próximas ao coração, que ouve complacente as palavras proferidas pelo anjo, deixando-se iluminar ora pelo Espírito Santo, ora pelo fólio entreaberto à sua frente. Em alguns quadros o manuscrito em questão é a própria Bíblia, já em outros a leitura é feita em um Livro de Horas no qual a página ciosamente confere destaque à seguinte passagem de Isaías (7:14): - "Portanto o Senhor mesmo vos dará um sinal: eis que uma virgem conceberá e dará à luz um filho".

Figura 2 - Reprodução da parte central do quadro "Tríptico da Anunciação", de Rogier van der Weyden (1434-1440).

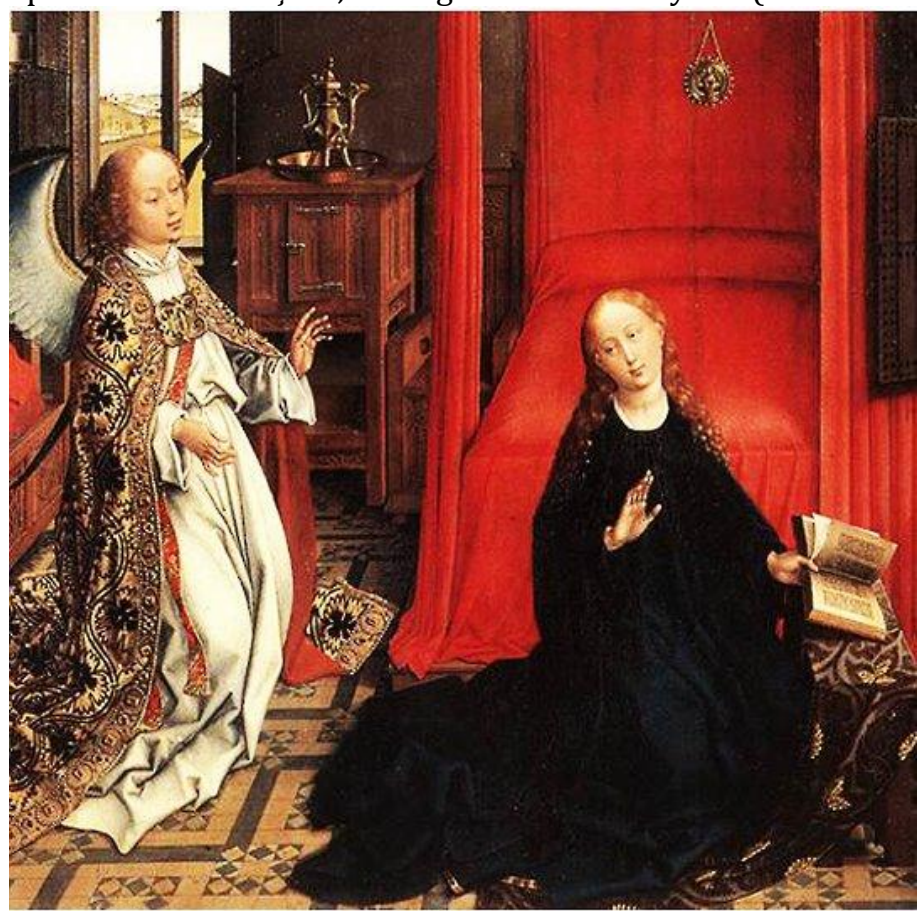

Fonte: Weyden (1434-1440). 
Figura 3 - Reprodução da obra “Anunciação”, de Joos van Cleve (1525).

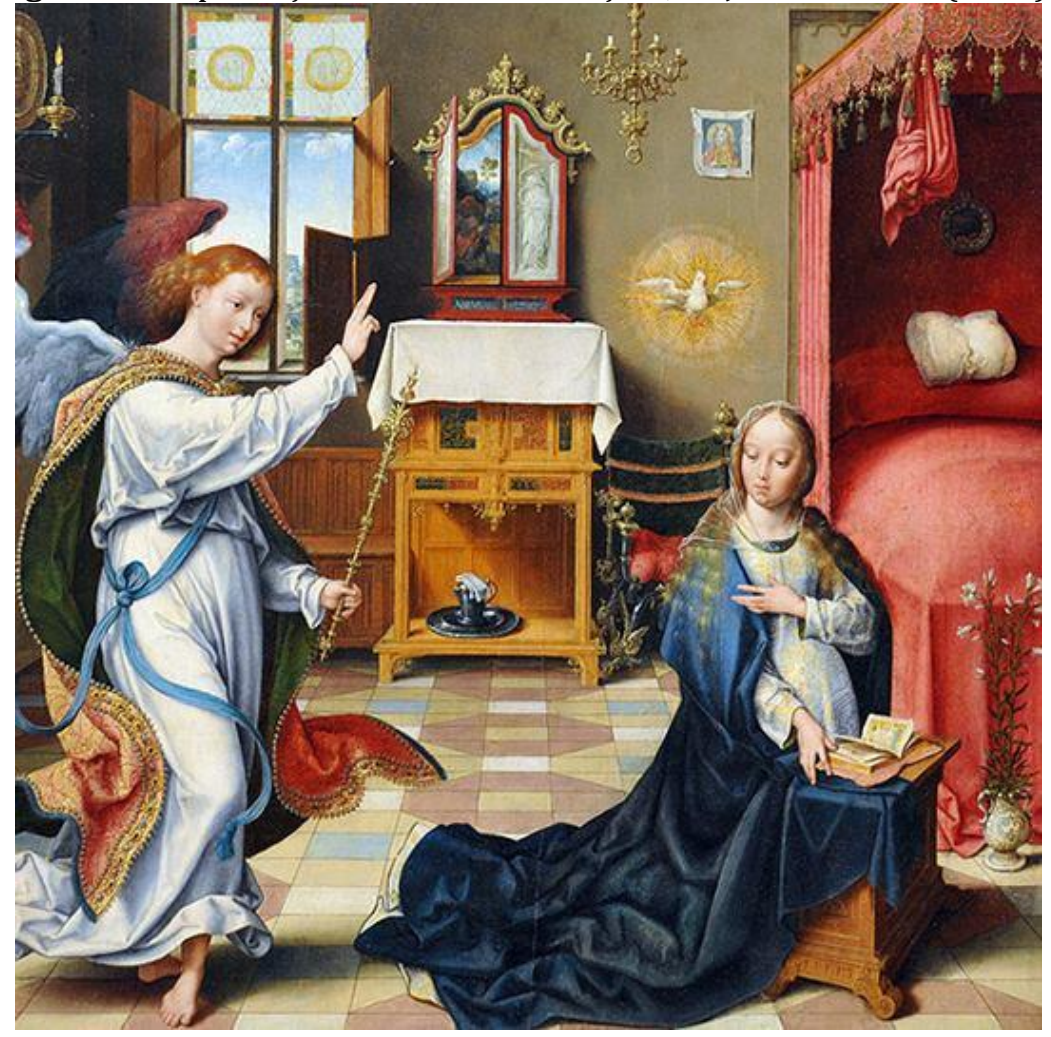

Fonte: Cleve (1525).

Modalidades de enquadramentos da leitura que servem também como descritores de dois outros conjuntos de representações aqui mencionados: as imagens de santas e a arte funerária. Tanto em uma figuração quanto na outra, a divisão dos espaços masculinos e femininos se torna ainda mais evidente. Para as mulheres, a leitura ainda é concebida como um ato de sujeição à palavra divina, como um preceito que deve ser interiorizado, assimilado e seguido sem qualquer tipo de contestação, sob pena de ter sua santidade maculada, razão pela qual a relação com o livro e a leitura enseja um gesto de contrição, penitência e arrependimento.

Preceitos claramente visualizados, por exemplo, nos retratos de Maria Madalena, a prostituta arrependida que escolhe um caminho de purificação e penitência. De modo geral, a conversão de Madalena institui uma via de salvação possível para as mulheres que, em algum momento de suas vidas, deixaram-se tocar pelo pecado da luxúria. "Dividida entre esperança e temor, ela torna-se acusadora de seus pecados, e é essa confissão que a salva. Mais: torna-se por sua vez agente de redenção." (DALARUN, 1990, p.48).

Indícios simbólicos endossados e potencializados pelas representações visuais da santa. Ganhando impulso a partir do século XI, o culto a Madalena difunde-se tendo por refe- 
rência a imagem de uma jovem vivendo uma vida de eremita, longe da companhia dos pais, entregue à penitência e castigando seu corpo, seja por meio da auto-flagelação ou de jejuns. Sua nudez, ao mesmo tempo que emerge como símbolo da luxúria, aponta para um caminho de salvação do corpo feminino via imposição de martírios. Completam esse argumento estético três elementos figurativos: a cruz, o crânio e o livro. 0 primeiro reforça que a redenção só vem através de Cristo e da veneração ao seu sacrifício. 0 crânio, incorporando as virtudes da prudência, mantém em estado de vigilância tanto o comportamento da Santa - "vá, e não peques mais". (João, 8:11) -, quanto a atividade leitora que se exerce. Isto porque, ainda aqui, a leitura feminina é um ato passivo e condicionado aos desígnios de uma sociedade que mantém as mulheres fora do convívio social e sob o julgo da religião e dos maridos.

Referências que têm seu contraponto na imagem dos santos leitores, especialmente na figura de São Jerônimo. Para este a leitura é uma atividade criadora quase sempre representada por uma ação dupla: ele lê e escreve a um só tempo. Além disso, sua cela ou scriptorium, inversamente aos claustros femininos, nunca possui apenas um único volumen, posto acumular vestígios de conhecimentos materializados em obras de distintos autores e períodos.

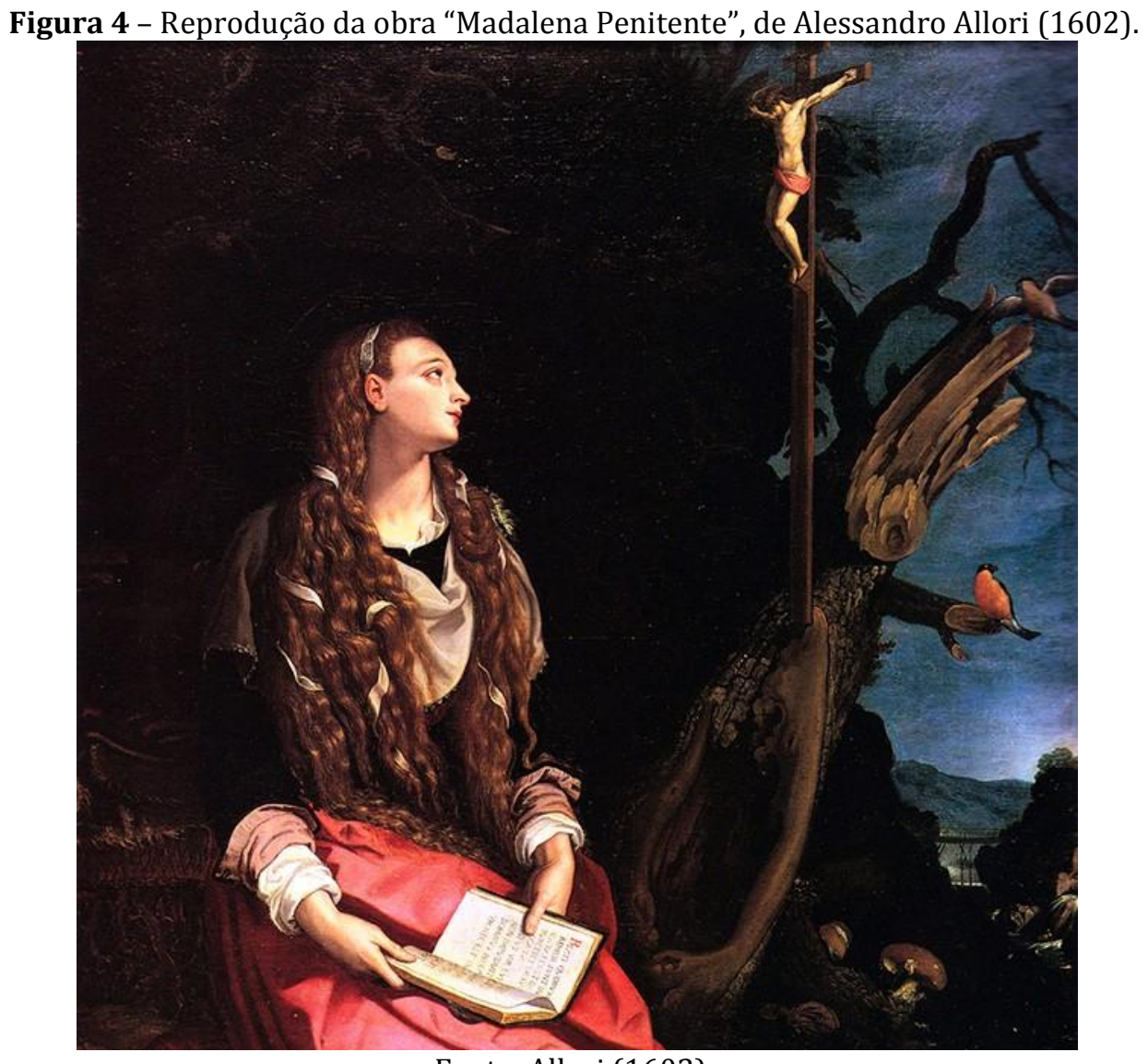

Fonte: Allori (1602). 
Representações visuais da mulher leitora: notas sobre as transmutações de uma prática cultural

Figura 5 - Reprodução da obra “Maria Madalena no deserto”, de Emmanuel Benner (1886).

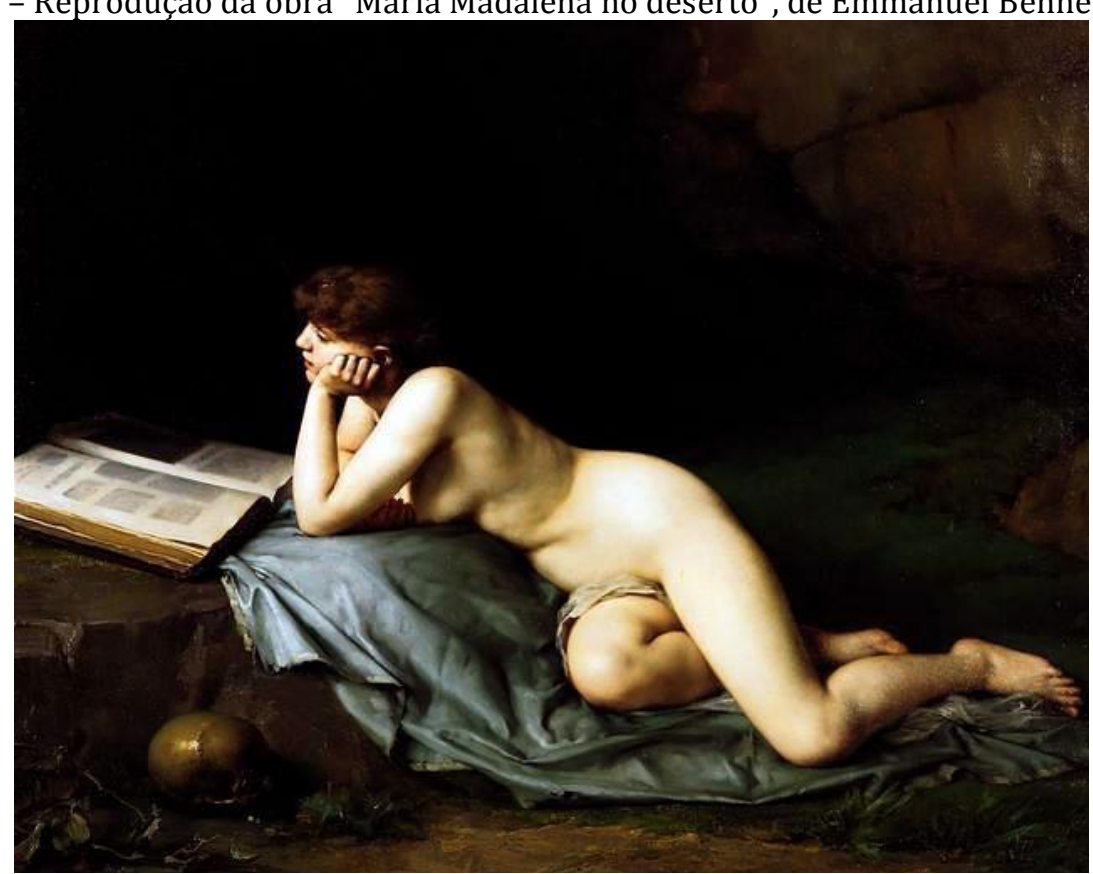

Fonte: Benner (1886).

Figura 6 - Reprodução da obra “São Jerônimo no scriptorium”, de Antonio da Fabriano (1451).

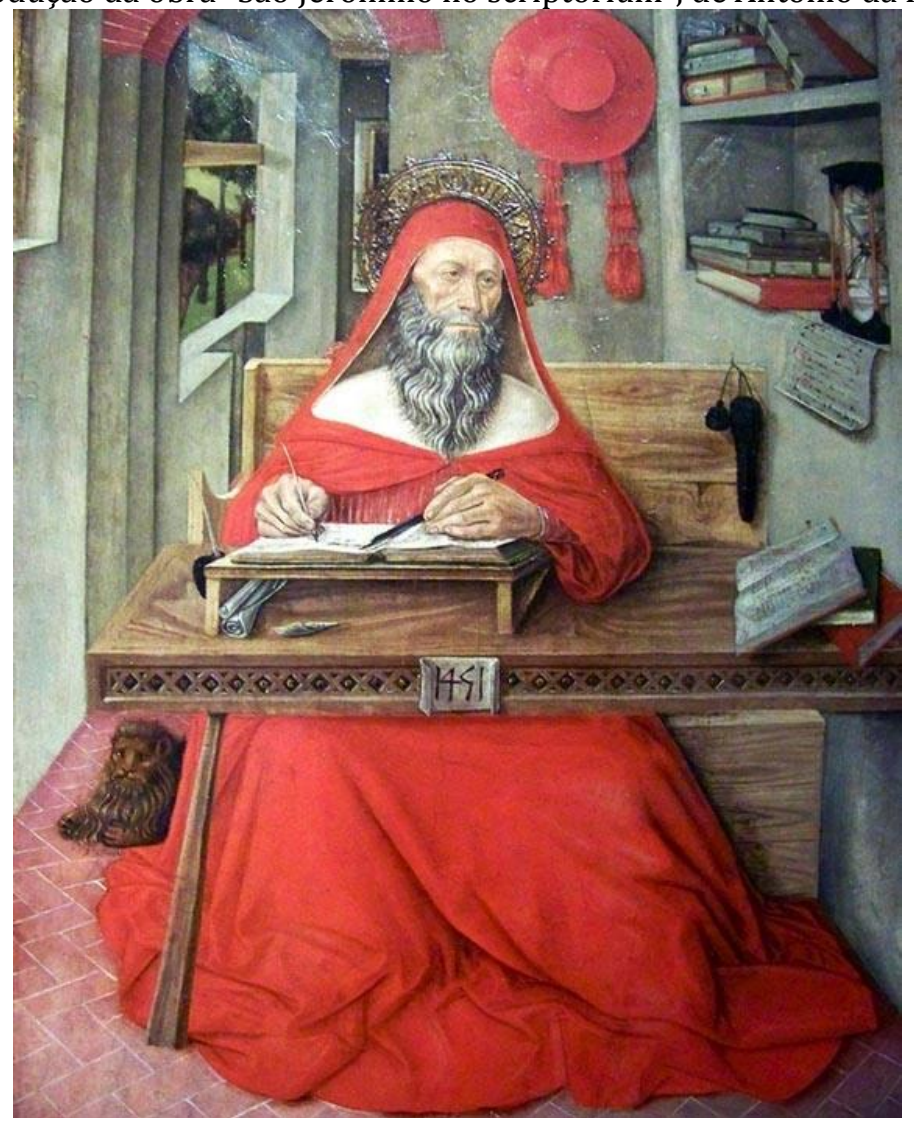

Fonte: Fabriano (1451). 
Assimetria perpetuada até no momento da morte, uma vez que, por serem considerados mais fortes física e espiritualmente, os homens repousam munidos de sua espada, enquanto a nobre dama carrega consigo seu livro pessoal de orações.

Figura 7 - Escultura fúnebre para a tumba de Leonor de Aquitania, França,

Abadia de Fontevraud (1122 - 1204)

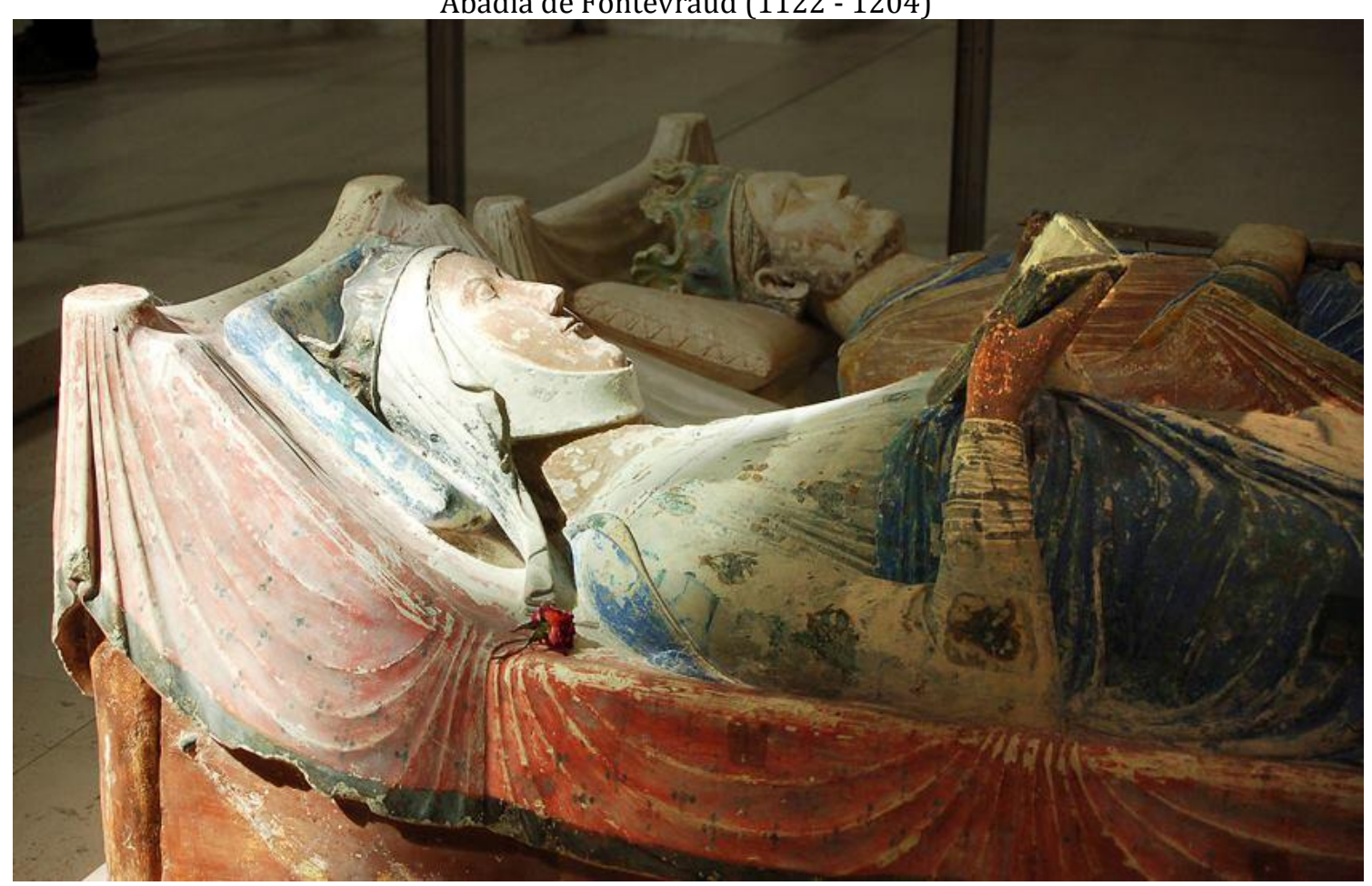

Fonte: Abadia de Fontevraud

O exemplo acima, apesar de demarcar fronteiras muito claras entre os domínios masculinos e femininos no contexto medieval, acena para os desvios que a leitura silenciosa podia oferecer às mulheres. Mesmo àquela época já era possível ler em segredo e aproximar-se de certos conhecimentos de modo direto, fazendo referências cruzadas, comparações e permitindo que os pensamentos fluíssem em um nível superior de consciência, condição que, em última instância, conferia a elas um universo íntimo preservado da censura e do olhar dominador de seus pais, padres, filhos e maridos. Dessa forma, ler em silêncio, como nos ensina a escultura jacente de Leonor de Aquitania, “[...] podia ser considerado um símbolo de alegrias celestiais, em especial no caso de uma mulher que se tinha distinguindo em vida como padroeira das artes e da literatura, e que passou os últimos anos de sua existência num convento". (BOLLMANN, 2007, p.27). Daí o olhar etéreo e complacente para o livro que acompanha sua jornada além-túmulo. 
A essas três representações das práticas de leitura feminina inscritas no mundo medieval, devemos acrescentar uma quarta: as imagens de Sant'Anna Mestra ao lado da Virgem e do Menino Jesus. Ganhando notoriedade nos anos finais da Idade Média, já quase na transição para o Renascimento, esse outro referencial iconográfico, mais que preconizar um tipo de leitura e como a mesma deveria ser executada, aponta para as responsabilidades da mulher enquanto mãe e esposa, bem como o seu compromisso com a educação familiar e a preservação dos preceitos da fé.

Aqui, diferentemente do olhar contrito que se volta para o alto ou para a face do anjo à espera de uma revelação, observa-se a transmutação da leitura em gesto ativo e enunciativo. O livro é colocado mais próximo do corpo, demarcando uma situação de maior intimidade tanto com o objeto manipulado quanto com as mensagens e ensinamentos que ele enseja. 0 dedo em riste e apontado para o texto, além de acompanhar o desenvolvimento da leitura, sublinha aquilo que de importante deve ser apreendido, discernimento adquirido graças à iluminação divina, mas também pelo acúmulo de experiências que emanam de uma vida longa e santa.

No entanto, é preciso fazer notar que, embora as figurações da natividade e da família nazarena estejam envoltas por um clima plácido e amável, cujo afeto manifesta-se essencialmente por intermédio da inserção das jovens crianças no universo da educação e da leitura, o pano de fundo aqui é, ainda, a supervalorização das obrigações femininas em relação à vida conjugal e à própria maternidade. Aspectos endossados por Tomás de Aquino ao referendar as palavras inscritas no Decreto I de Graciano, redigido entre os anos de 1140-1142, onde se lê: "Só a palavra privada lhe é permitida. Mesmo que seja douta e santa, não devem pretender ensinar os homens na assembleia". (AQUINO³ apud DALARUN, 1990, p.58). Daí a ausência, na grande maioria dessas representações, de qualquer figura masculina.

\footnotetext{
${ }^{3}$ Referência de Aquino, Súmula teológica, conforme consta em Dalarun (1990).
} 
Figura 8 - Reprodução da obra "Maria com o menino que lê", de Jan van Eyck (1433).

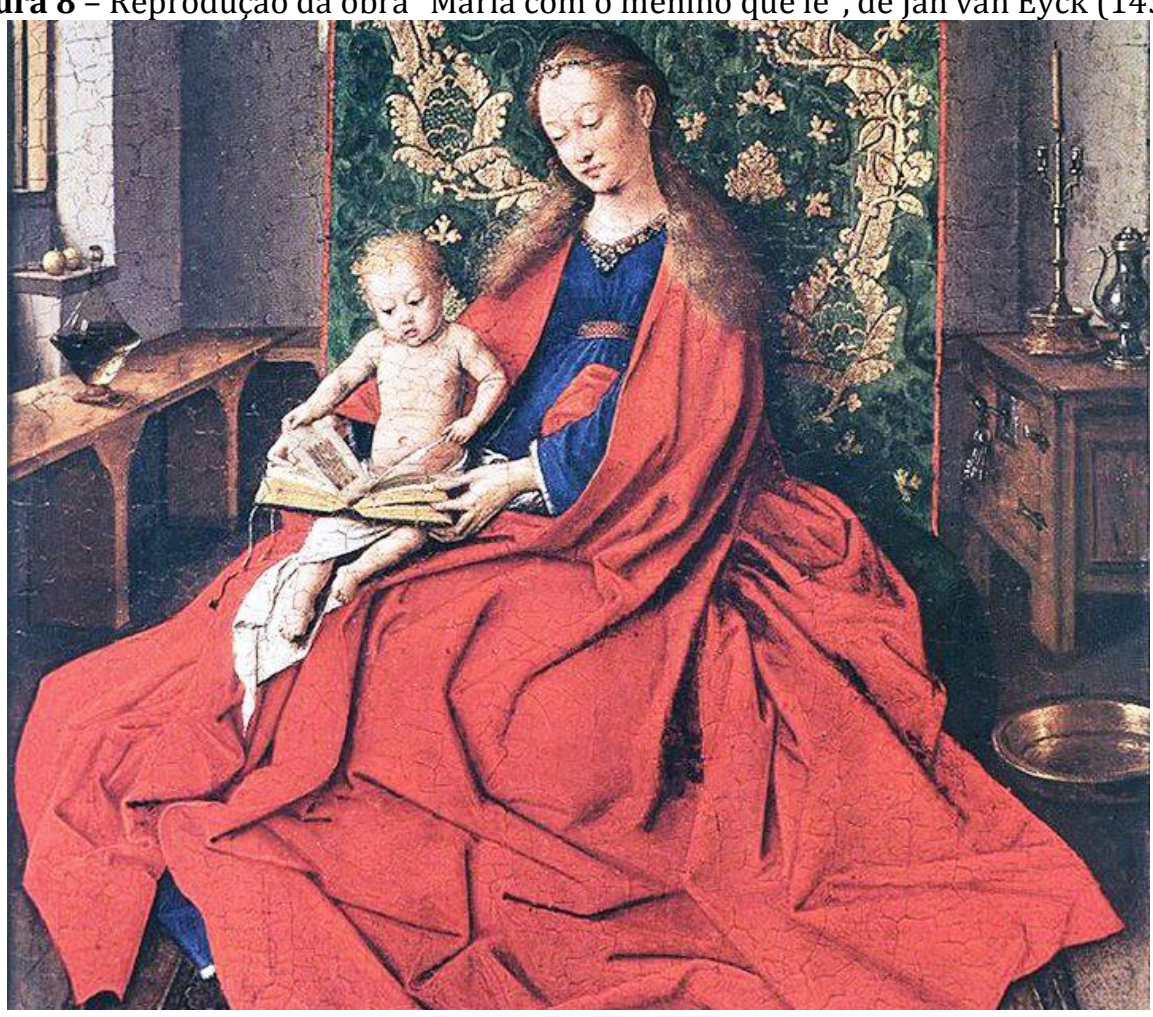

Fonte: EYCK (1433)

Figura 9 - Reprodução da parte central do quadro "Educação da virgem", de Giambattista Tiepolo

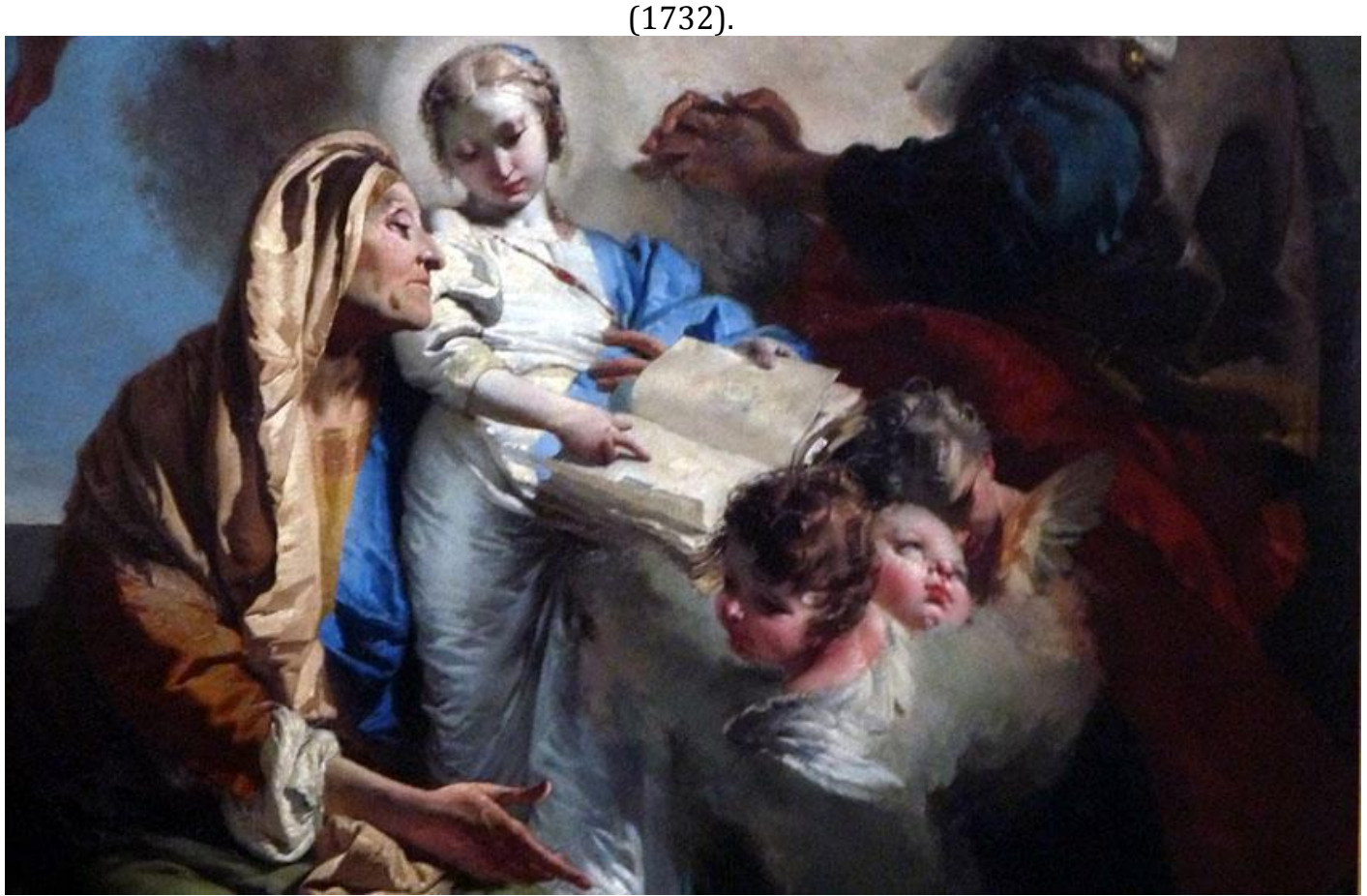

Fonte: Tiepolo (1732). 
Como síntese, é possível se apontar que, devido à profusão de imagens que representam os gestos leitores empreendidos pelas mulheres no contexto medieval, a capacidade de leitura estava provavelmente mais difundida entre elas do que normalmente os historiadores costumam admitir. Além disso, há dois modelos de leitoras que aparecem com maior força: a moça casta que, para se manter enquanto tal, executa em silêncio e na solidão do seu quarto as orações bíblicas inscritas em seus livros de horas; e o modelo da mãe zelosa que cuida da casa e do marido, ao mesmo tempo em que se faz responsável pela educação dos filhos. Modalidades figurativas que serviram de referência para retratar as práticas de leitura feminina até os séculos XVIII e XIX, quando a ascensão do romance e a consolidação de movimentos artísticos como o Romantismo, o Impressionismo e o Expressionismo deram novas feições para tal ato. É isso que veremos a seguir.

\subsection{Séculos XVIII e XIX: da leitura de lazer aos impulsos erotizantes}

Três fatores histórico-sociais contribuíram sobremaneira para uma reorientação do imaginário representacional das práticas de leitura feminina entre os séculos XVIII e XIX, são eles: um aumento exponencial dos índices de alfabetização nos vários países europeus; a constituição de centros urbanos e industriais e a conversão do romance, especialmente o folhetim, na expressão literária clássica da sociedade burguesa. Embora ainda predominasse uma divisão sexual das tarefas ligadas à leitura e à escrita - as mulheres liam para a família e os homens cuidavam da escrita e da contabilidade -, a presença de novos segmentos populacionais/ocupacionais no universo de tais práticas (empregadas domésticas, balconistas, por exemplo); fomentou a emergência de um mercado livreiro dedicado especialmente a elas: livros de culinária, revistas (sobretudo de moda) e, especialmente, romances de massa.

Além de todos esses fatores, é preciso levar em consideração que o século XIX impulsionou a emergência de um fenômeno relativamente novo: o da mulher com pretensões literárias. Essa novidade, mesmo que tenha sido ridicularizada sem piedade por alguns jornais da época, como o satírico Le Charivari, sob o argumento de que colocaria em risco a estabilidade doméstica, nas palavras de Martyn Lyons (2002); contribuiu sobremaneira para reorientar a percepção coletiva acerca da ocupação social de certos lugares e funções por parte do público feminino.

A notoriedade de algumas poucas pessoas, como George Sand, não deve mascarar as contribuições literárias feitas de maneira generalizada e por toda parte pelas mulheres no século XIX. A "femme de lettres" (mulher de letras) havia chegado para ficar. (LYONS, 2002, p.168). 
Esse conjunto de transformações paulatinamente reconfigurou os índices de simbolização que até então eram acionados para se produzir representações figurativas das práticas de leitura feminina. Se antes a imagem tradicional da mulher que lia tendia a ser a de uma leitora com motivações religiosas e voltada para a educação e manutenção da ordem familiar, estando, por isso, afastada das preocupações que mobilizavam a vida pública, as mulheres leitoras desse período serão representadas quase sempre consumindo romances de massa. 0 que não quer dizer, em termos de imaginário social, uma ruptura significativa com as polarizações de gênero até aqui instituídas, uma vez que a feminilização do público leitor de romances parece confirmar os preconceitos dominantes sobre o papel da mulher e sua inteligência. Isto porque:

Romances eram tidos como adequados para as mulheres por serem elas vistas como criaturas em que prevalecia a imaginação, com capacidade intelectual limitada, frívolas e emotivas. 0 romance era a antítese da literatura prática e instrutiva. Exigia pouco do leitor e sua única razão de ser era divertir pessoas com tempo sobrando. Acima de tudo o romance pertencia ao domínio da imaginação. Os jornais, com reportagens sobre eventos públicos, pertenciam geralmente ao domínio masculino; os romances, que tratavam de vida interior, eram parte da esfera privada à qual eram relegadas as mulheres burguesas do século XIX. Isso representava certo perigo para o marido e para o pater familias burguês do século XIX: o romance poderia excitar as paixões e exaltar a imaginação feminina. Poderia incentivar expectativas românticas que pareciam pouco razoáveis; poderia sugerir ideias eróticas que ameaçavam a castidade e a boa ordem. 0 romance do século XIX era, pois, associado com as (supostas) características femininas de irracionalidade e de vulnerabilidade emocional. (LYONS, 2002, p. 171-172).

De acordo com esse imaginário, as cenas abaixo, além de confirmarem visualmente os enunciados presentes na citação, acabam por indicar que entre os séculos XVIII e XIX dois tipos de composição/argumentos estéticos são frequentemente acionados quando o intuito é representar a leitura feminina. No primeiro conjunto, devido ao entendimento de que as mulheres são frívolas e emotivas por natureza, a leitora de romances aparece refugiada em paisagens idílicas, onde pode ler em paz e completamente absorta em seus livros. Em paralelo a esse modelo, encontravam-se aquelas que liam em segredo e que utilizavam o livro como um instrumento capaz de lhes proporcionar prazeres fortuitos e altamente erotizantes. 
Figura 10 - Reprodução da obra "Reading the Will", de David Wilkie (1820).

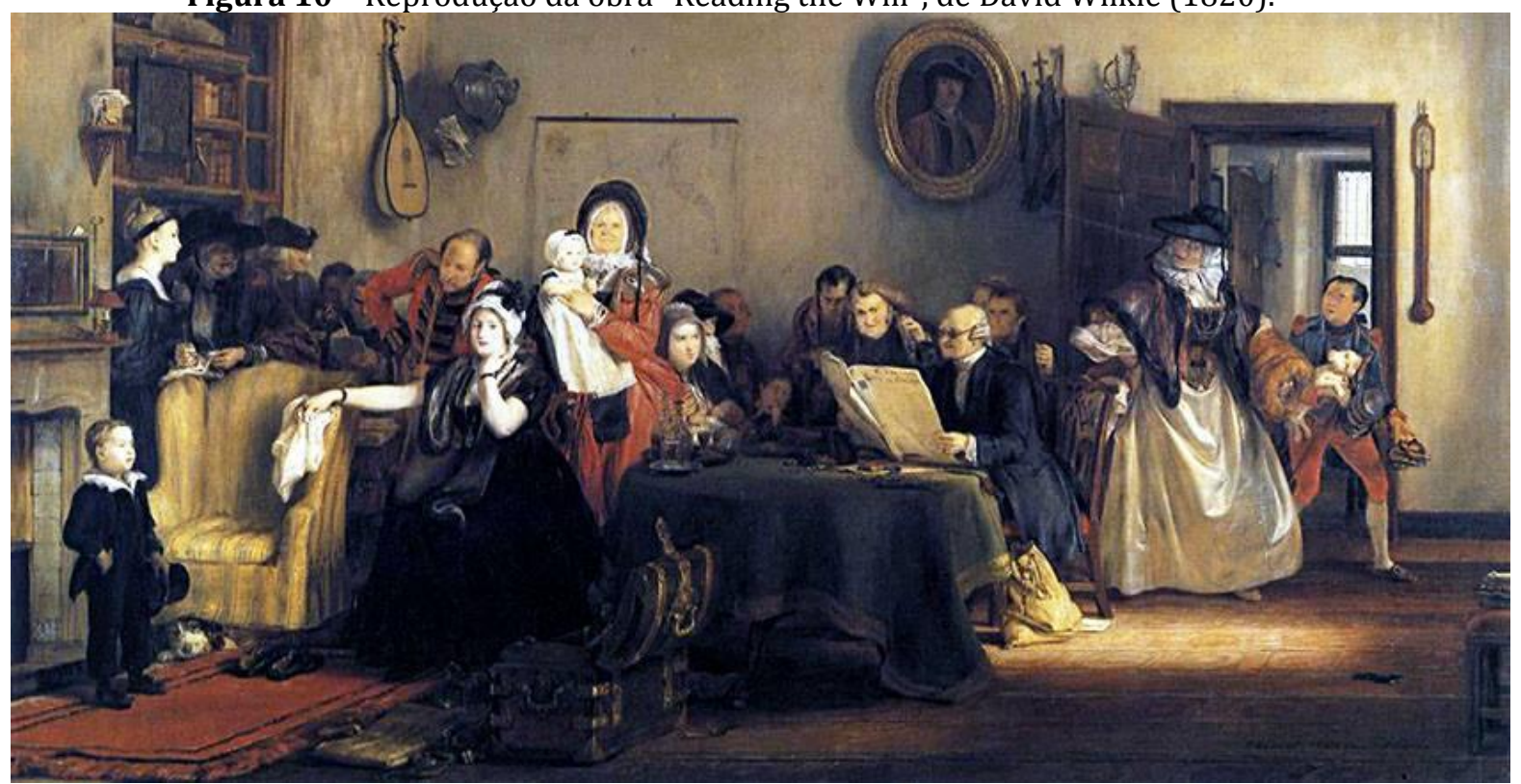

Fonte: Wilkie (1820).

Figura 11 - Reprodução da obra “A sentimental”, de Johann Peter Hasenclever (1847).

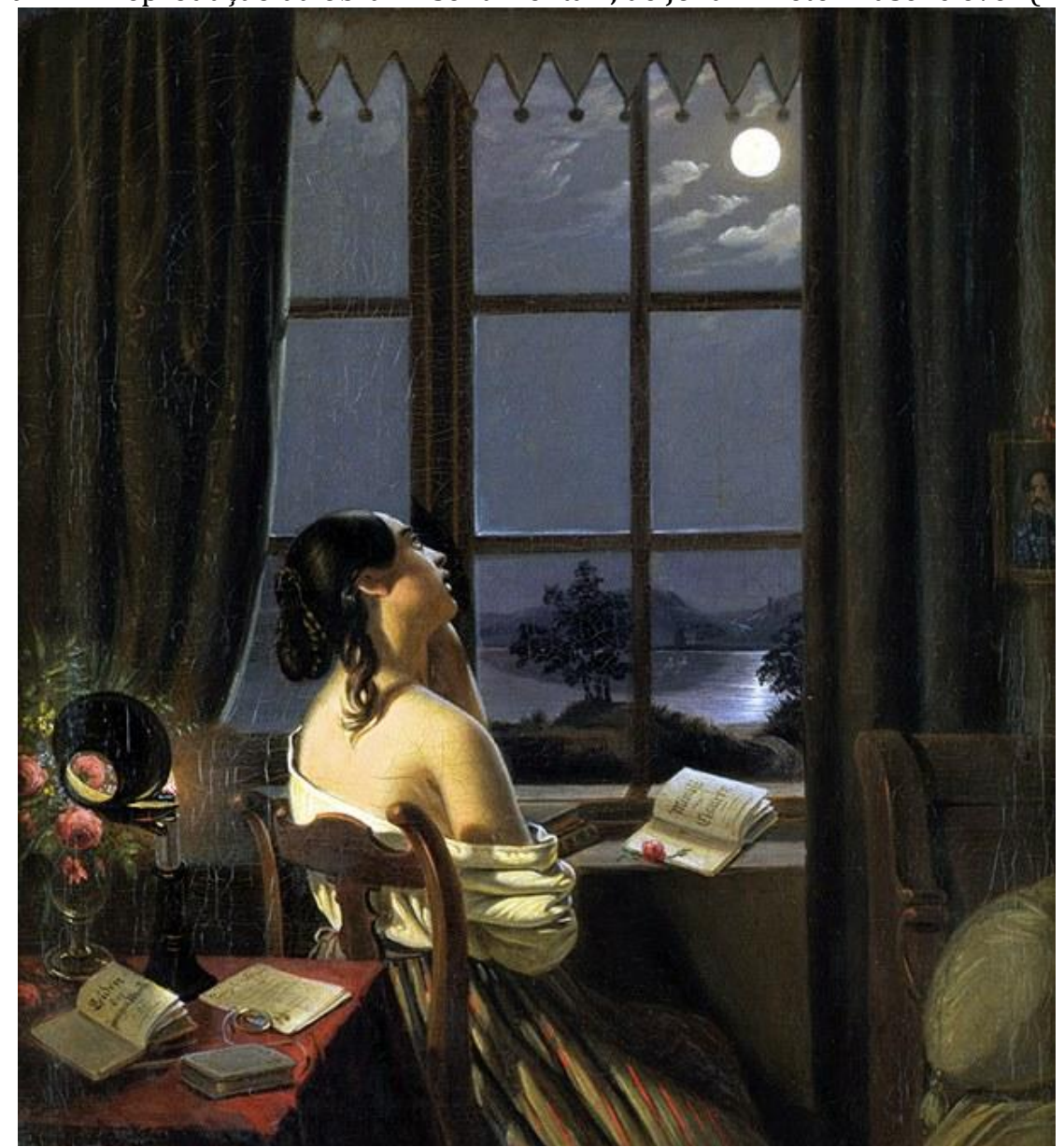

Fonte: Hasenclever (1847). 
Figura 12 - Reprodução da obra "Moça que lê", de Theodore Roussel (1887).

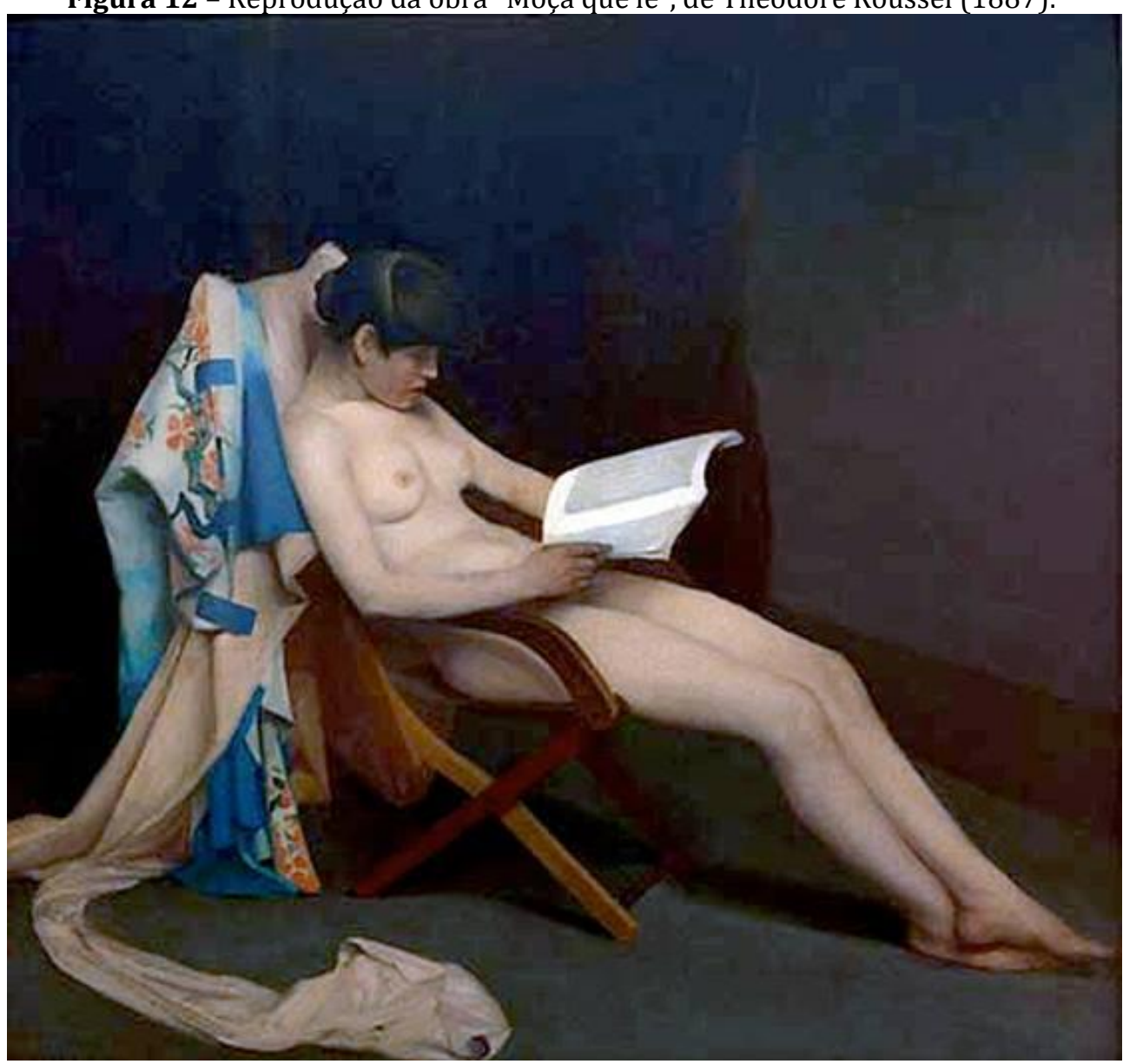

Fonte: Roussel (1887).

No primeiro caso, em função da leitura de romances ser considerada um desperdício do tempo produtivo, criou-se em torno de tal prática um estereótipo claramente estruturado para se referir às mulheres como eternas consumidoras de material de leitura leve, trivial e romântico. Tidas como emocionalmente frágeis e facilmente influenciadas, era comum acreditar que as mulheres recorriam aos romances porque sua leitura lhes propiciava experimentar certos sentimentos individuais específicos como prazer, amor, tristeza e contentamento. Além desses, a identificação/projeção com certas personagens conferia às moças e senhoras que liam tais obras a possibilidade de escapar, ao menos em termos psicológicos, da demarcação de papéis socialmente instituídos, aumentando assim sua autoestima e dotando-lhes de "[...] uma nova e deliciosa consciência de si próprias". (BOLLMANN, 2007, p.30). Não por acaso, são quase todas representadas lendo sozinhas, de maneira silenciosa e completamente absorvidas por seus livros. 
Figura 13 - Reprodução da obra "The Novel: a lady in a garden reading a book", de Frank Dicey

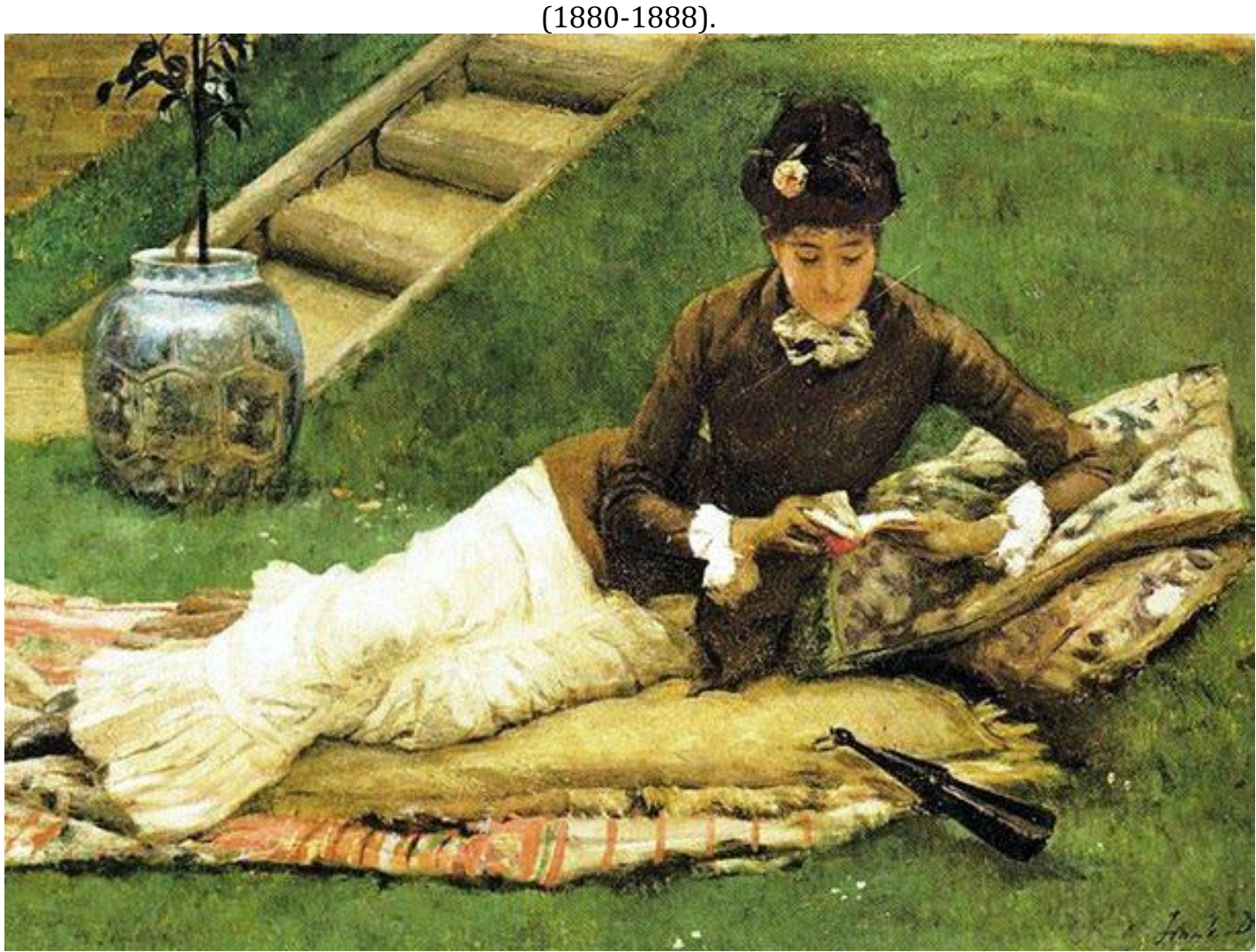

Fonte: Dicey (1880-1888).

Figura 14 - Reprodução da obra "Sonhadora", de John Henry Niemeyer (1881).

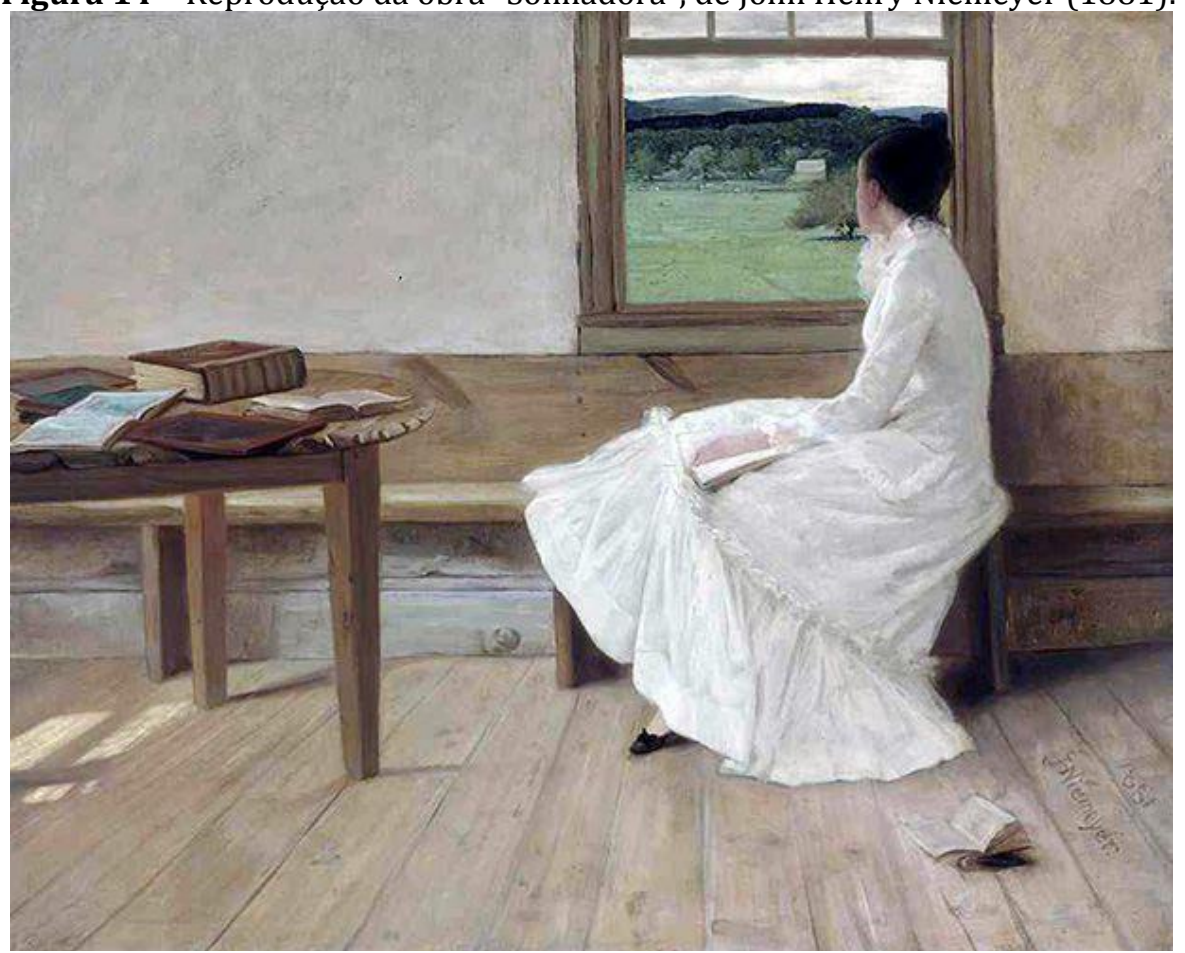

Fonte: Niemeyer (1881). 
Contudo, não devemos esquecer que as mulheres ainda não conquistaram sua independência, ficando, quase sempre, em posição de tutela em relação ao homem. As que violavam essa regra liam em segredo. A essas, os livros asseguravam um "efeito de leitura" que incidia diretamente na forma como experimentavam o prazer e cultivavam suas fantasias. Nesses termos, a leitura de romances era considerada uma prática perigosa para as mulheres porque, de acordo com o "espírito da época" - "[...] impunha um só e único comportamento. Incapaz de satisfazer o desejo que suscitou, ele obriga o leitor a sair do mundo imaginário para impor a lei do livro ao mundo real". (GOULEMOT, 2000, p.64). Por isso a grande quantidade de imagens onde as leitoras estão na cama, lendo à meia-luz, com o corpo despido e intumescido. Não raro são apresentadas segurando os livros com apenas uma das mãos, indicativo de que a outra serviria como um recurso de auto-excitação.

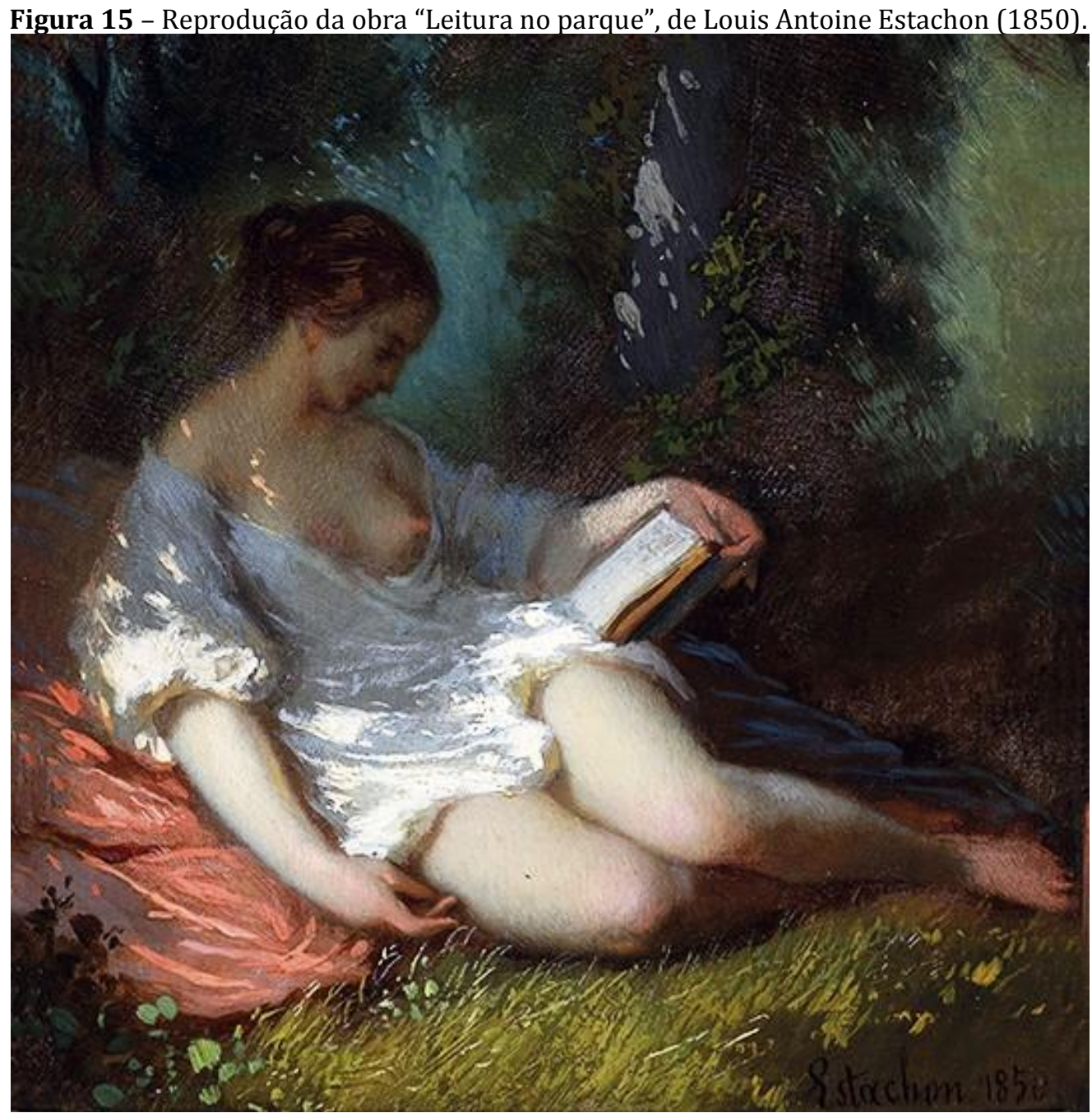

Fonte: Estachon (1850). 
Figura 16 - Reprodução da obra "O leito ávido", de Hermann Fenner Behmer (1906).

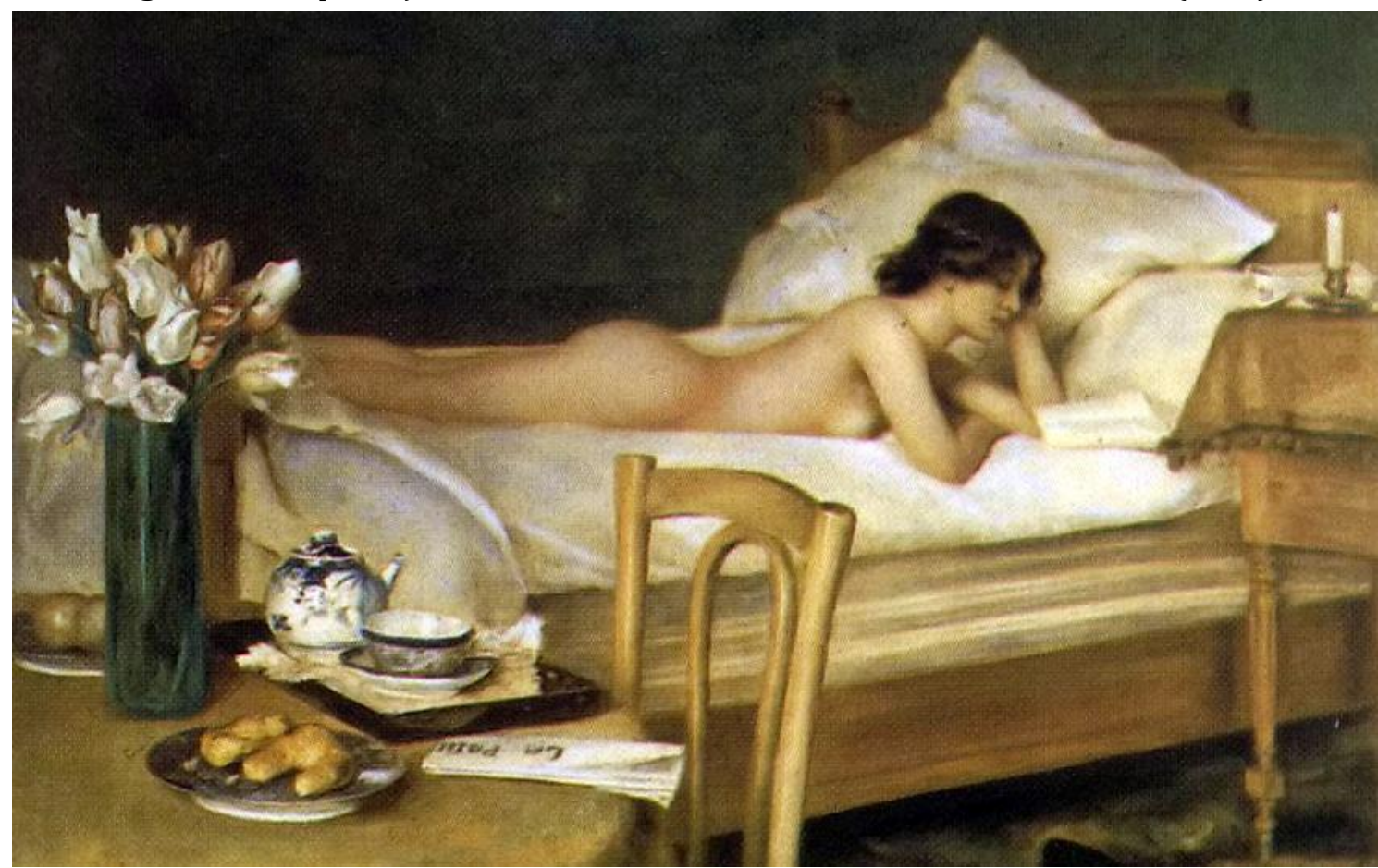

Fonte: Behmer (1906).

Substrato simbólico que só começa a se alterar nas primeiras décadas do século XX quando a emancipação feminina ganha força e o acesso à informação converte-se em direito universal. A partir daí, novas concepções de leitura são formuladas, ensejando, também para as mulheres, outras representações de suas práticas leitoras. Vejamos como isso se dá na próxima seção.

\subsection{Da segunda metade do século $X X$ aos dias atuais: a leitura está em toda parte}

Os anos iniciais da década de 1950 já apontavam para uma guinada tecnológica que causaria impactos diretos e imediatos nas nossas práticas de leitura. 0 desenvolvimento das tecnologias de informação e do conhecimento - TICs - e a emergência dos domínios virtuais acabaram por acenar para uma paulatina transformação no que concerne aos aspectos materiais do livro, fazendo com que este conviva lado a lado com textos sem lugares. Isso acarretou a institucionalização de novas maneiras de ler, novas relações com a escrita e a adaptação das técnicas intelectuais utilizadas para se exercitar tais atividades.

Isso se dá porque o texto eletrônico é um domínio móvel, maleável e aberto que permite usos, manuseios e intervenções muito mais numerosas e livres que qualquer um dos 
antigos formatos do livro. Movimentando a barra de rolagem e trilhando os caminhos sinalizados pelos links hipertextuais, o leitor de um documento eletrônico não é mais constrangido a intervir nas margens, no sentido literal ou no sentido figurado que define esse termo. Ao contrário, ele pode atuar no coração, no centro gerador da escritura. Indo mais além:

A textualidade eletrônica permite desenvolver as argumentações e demonstrações segundo uma lógica que já não é necessariamente linear nem dedutiva, tal como dá a entender a inscrição de um texto sobre uma página, mas que pode ser aberta, clara e racional graças à multiplicação dos vínculos hipertextuais. Por outro lado, e como consequência, o leitor pode comprovar a validade de qualquer demonstração consultando pessoalmente os textos (mas também as imagens, as palavras gravadas ou composições musicais) que são o objeto da análise se, evidentemente, estiverem acessíveis numa forma digitalizada. (CHARTIER, 2002, p. 24-25).

Não por acaso, conferir sentido às práticas de leitura e escrita no mundo contemporâneo pressupõe abdicar dos hábitos adquiridos até este momento e buscar apreender suas dinâmicas de reestruturação valendo-se de uma lógica que não está centrada nem em critérios dedutivos, nem em movimentos lineares. Ao contrário, sua exequibilidade está assentada na convergência de múltiplas modalidades de significação - arquivos, imagens, palavras, músicas - que se mostram abertas e fluidas por natureza. Estatuto ontológico que permite ao leitor submeter o texto a um sem-número de operações - ele pode indexá-lo, anotá-lo, copiá-lo, desmembrá-lo, recompô-lo, deslocá-lo, etc. - e tornar-se seu coautor. Atitudes perante o texto que podem "[...] levar esse leitor a efetivamente colher os sentidos possíveis dentro de seu mundo e aí então exercitar através do seu traço, de sua letra, de seu olho, uma experiência artística". (CASA NOVA, 2011, p.146).

Novidades que, somadas ao exercício interpretativo de correntes teóricas como a Semiologia, o Formalismo Russo, o New Criticism, os Estudos Culturais e a Estética da Recepção, só para citar algumas, reconfiguraram nossos modos de entender a leitura, bem como as práticas daqueles que a executam. De fato, ao repensarem as relações estabelecidas entre autor, obra e leitor, bem como o lugar social ocupado por cada um desses referentes no contexto geral dos atos de leitura, tais esforços investigativos colaboraram de maneira concreta para sairmos de um estágio mental que considera o gesto leitor como ato meramente de decodificação, para um outro onde a leitura é definida como um exercício ativo e coletivo de produção de sentido, constituindo-se, assim, como bem o observou Michel de Certeau (1994), em uma prática cultural atravessada pelo conjunto das normas, valores e condições técnicas presentes em cada localidade e em cada tempo histórico no qual se efetive. 
A Estética da Recepção, por exemplo, ao operar com os conceitos de efeito, recepção, emancipação, horizonte de expectativa e leitor implícito, defende que a leitura se constitui como uma prática interpretativa orientada pelo processo de interação que se estabelece entre a subjetividade do leitor e as diversas condições sócio-históricas a partir das quais determinado signo se originou. Concomitantemente, ao estabelecerem que o signo lido provoca, a partir de sua historicidade, uma reação, um efeito em seus leitores, pensadores como Hans Robert Jauss (1990) e Wolgang Iser (1996) passaram a atribuir à leitura uma natureza emancipatória capaz de liberar os leitores para participarem da criação dos textos que manipulam.

Nesses termos, se o sentido de uma obra passou a ser pensado como uma construção coletiva, a noção de "leitor ideal" que por tanto tempo se difundiu na história da leitura acabou tornando-se uma falácia, uma impossibilidade estrutural, visto que tal figura, para existir, deveria possuir as mesmas intenções que se manifestam no processo criativo. Em contraponto a esta ideia, a Estética da Recepção propõe o conceito de leitor implícito. Tal noção, percebida simultaneamente como uma estrutura textual e como um ato estruturado, não tem uma existência real, nem se funda em um substrato empírico, mas sim na própria natureza do texto. Isso significa dizer que as condições necessárias à existência e atualização do objeto de leitura se inscrevem em sua própria construção. Portanto, o efeito condicionado pela obra, apesar de oferecer uma orientação prévia quanto às formas de lê-la e quanto ao significado a ser apreendido, não reduz o leitor a um sujeito passivo à caça de uma mensagem original, mas propicia a este o direito de estabelecer inúmeras interpretações e imprimir na obra lida os rastros de sua atividade criativa.

Por isso apregoa-se agora que a leitura é um exercício de liberdade tanto quanto uma prática de sobrevivência. Lemos tudo e a qualquer hora, seja para nos informar, nos orientar pela cidade ou tão somente por distração e deleite. Ações que não são mais uma exclusividade dos leitores homens, posto que as mulheres também reivindiquem sua inserção e sua participação nessa nova conjuntura.

Movimento expresso de maneira inequívoca por muitas imagens que testemunham essa transição. Através delas o que se vê é que as mulheres passaram a ler em qualquer lugar e a lidar com uma quantidade multivariada de objetos leitores. 0 romance folhetim não é mais o seu livro de cabeceira, ao lado dele estão o jornal, os tratados acadêmicos, os exemplares de filosofia, os cadernos da escola, os textos de arte e poesia, assim como o tablet e/ou o smartphone. Elas ainda continuam lendo em casa, na cama e na escola, mas também 
o fazem na rua, na estação de trem, no hall do hotel, no ônibus, na praça pública e até mesmo no lixão, como nos mostrou o flagrante de Micah Albert. Podem ler sozinhas ou acompanhadas, mas é certo que dispensam aquela vigilância a que outrora lhes haviam submetido aos desígnios de pais, irmãos e maridos controladores e ciumentos ou às pressões da igreja, das subdivisões de gênero e classe, e daquelas instituições políticas que por tanto tempo colocaram-nas à margem da vida social. Constatações confirmadas e, em certa medida, até ampliadas pelas imagens que se seguem.

Figura 17 - Reprodução da obra "Lobby de hotel", de Edward Hopper (1943).

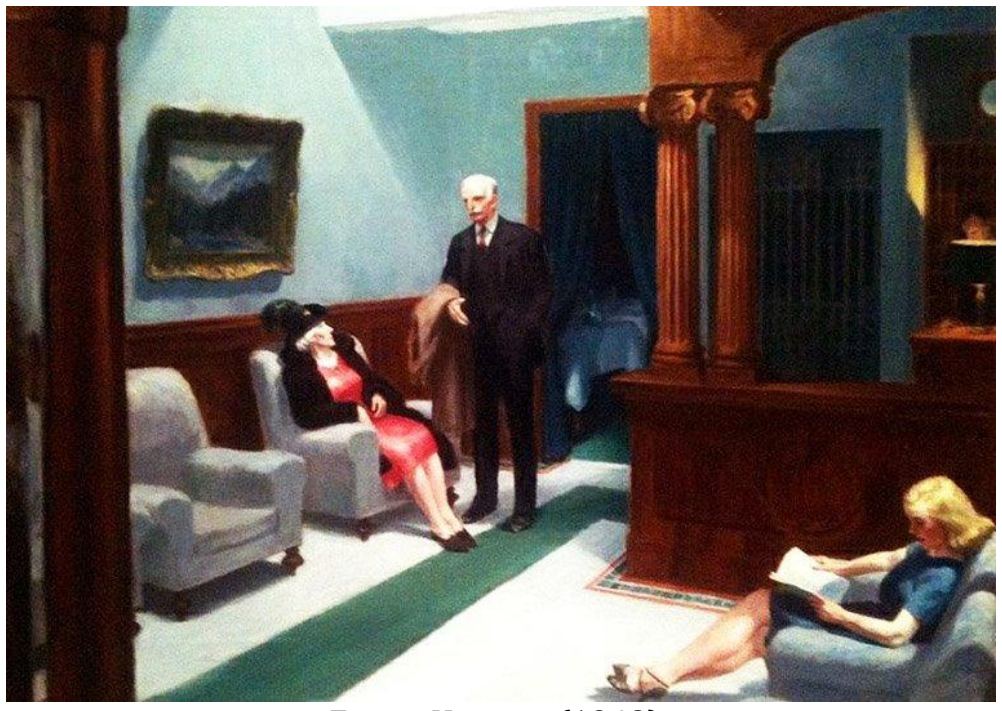

Fonte: Hopper, (1943).

Figura 18 - "Ônibus biblioteca na cidade de Levallois Perret, França". Reprodução da fotografia de Gérald Bloncourt (1960).

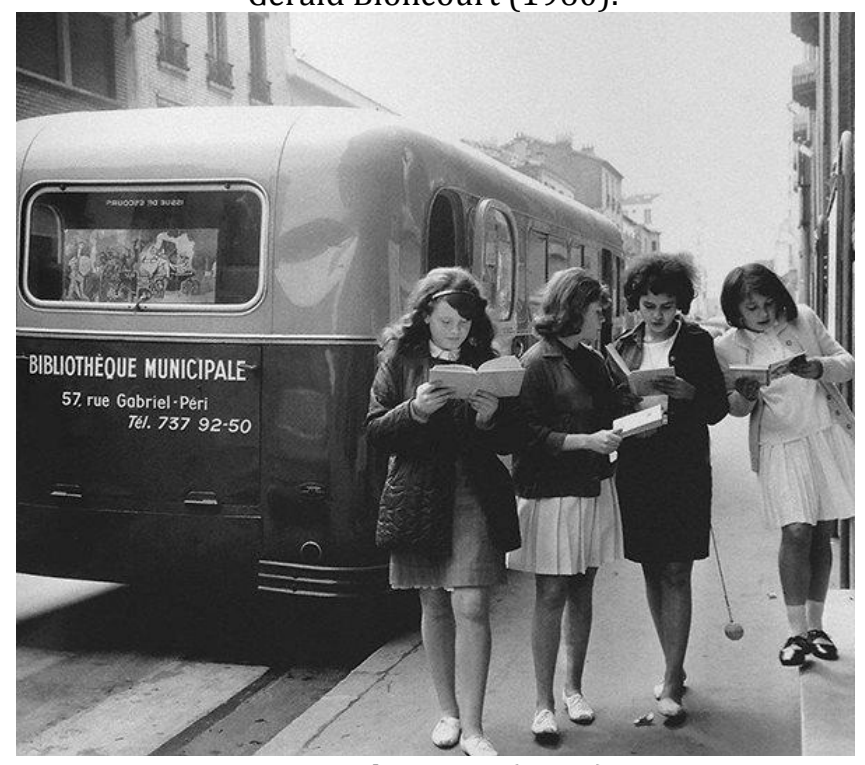

Fonte: Bloncourt (1960). 


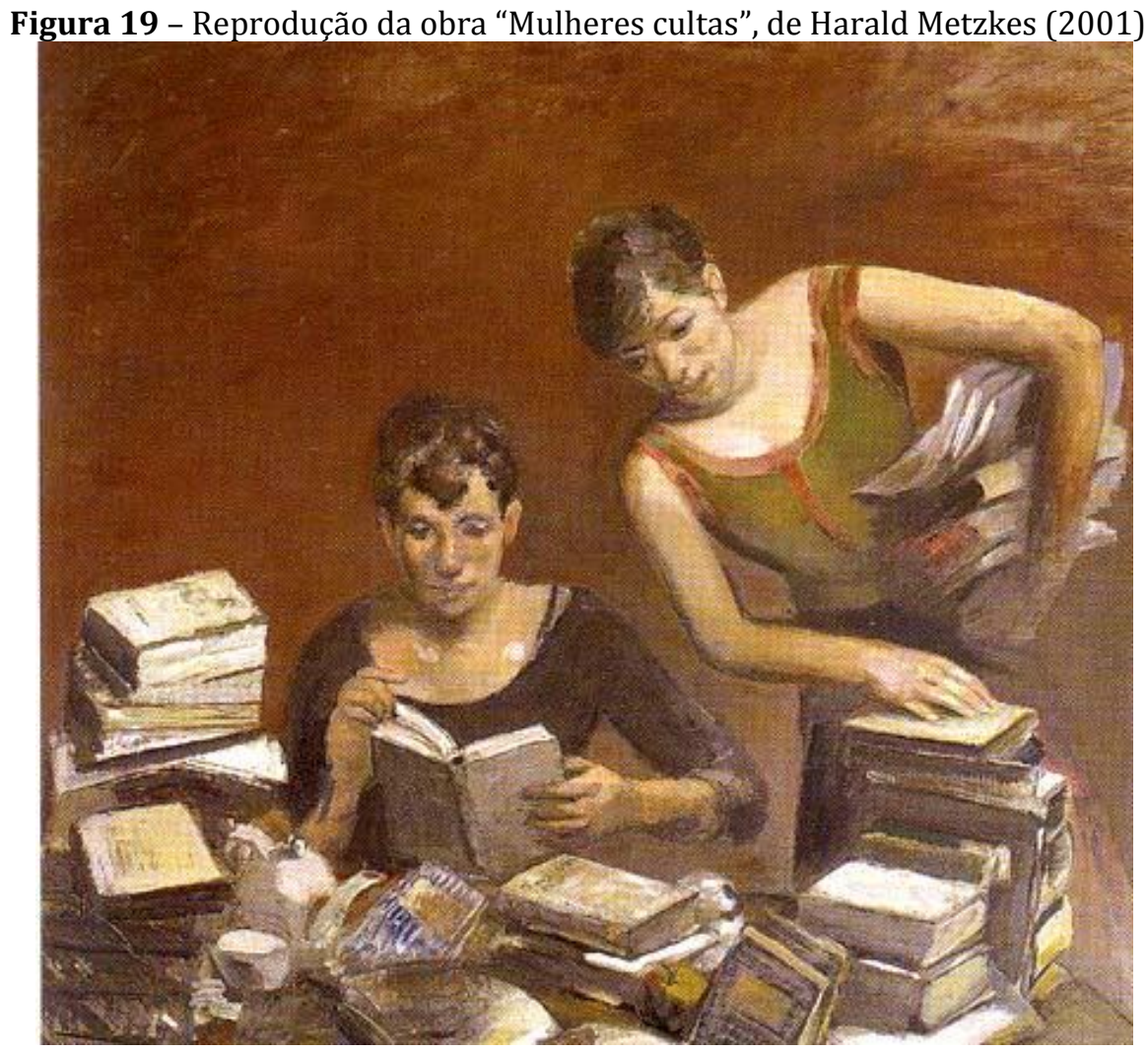

Fonte: Metzkes (2001).

Figura 20 - Reprodução da obra "Mulher lendo", de Fernando Botero (2002).

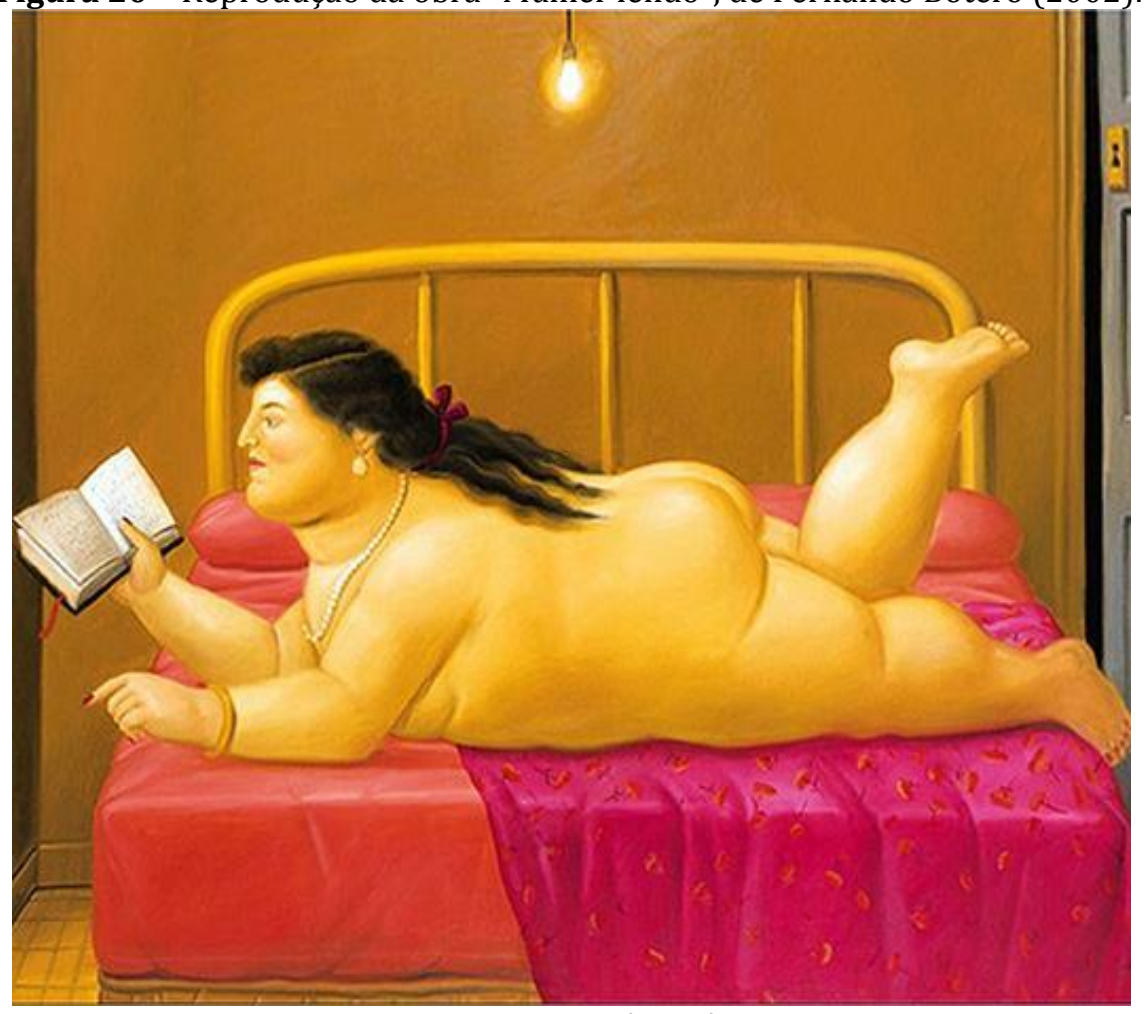

Fonte: Botero (2002). 
Figura 21 - Reprodução da obra "Leitura de verão", de Kurt Solmssen (2003).

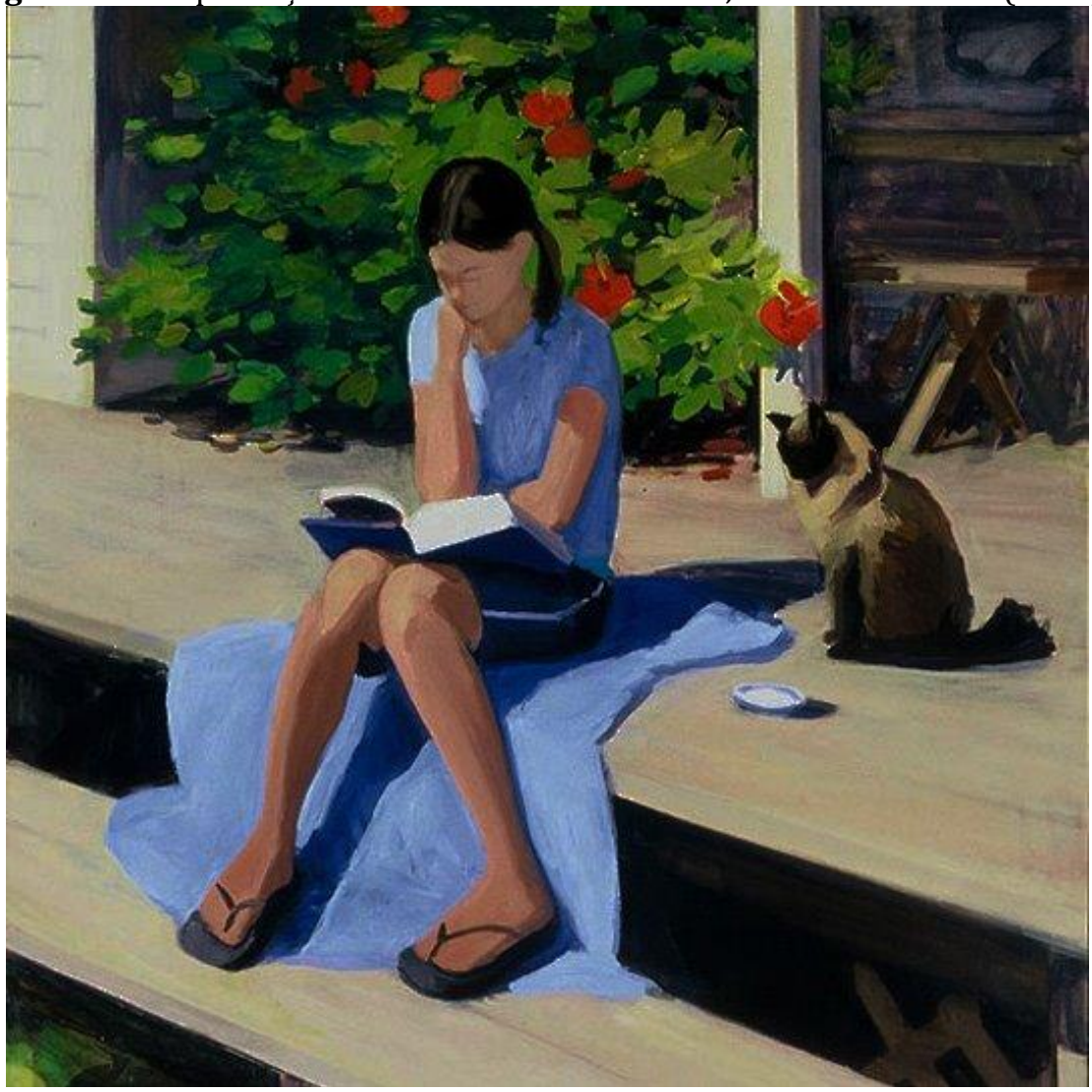

Fonte: Solmssen (2003).

Figura 22 - Reprodução da obra "Lendo na sala vermelha 2", de Delia Brown (2009).

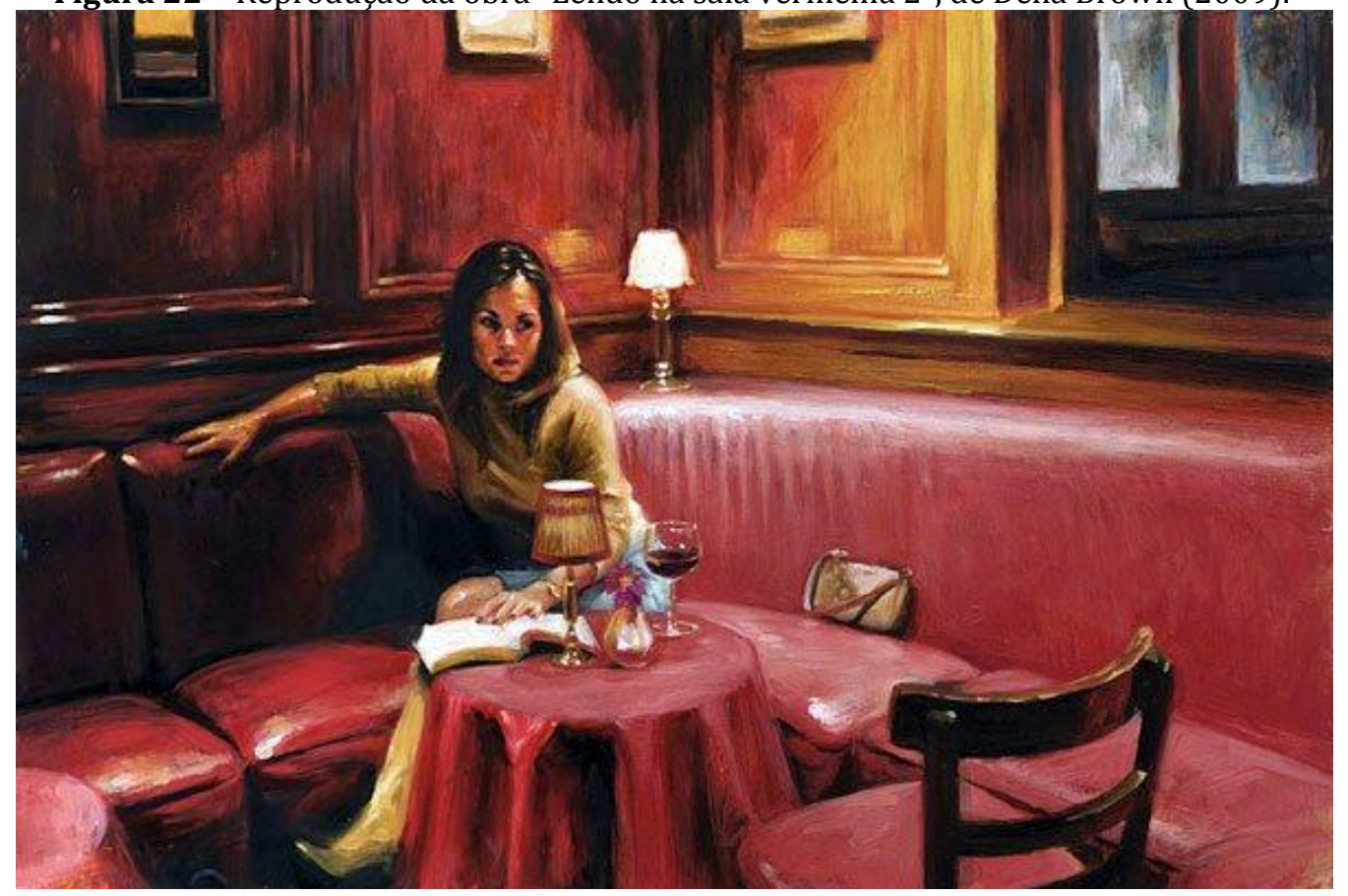

Fonte: Brown (2009). 
Figura 23 - “Na plataforma lendo”. Reprodução da fotografia de Mo Riza (2006).

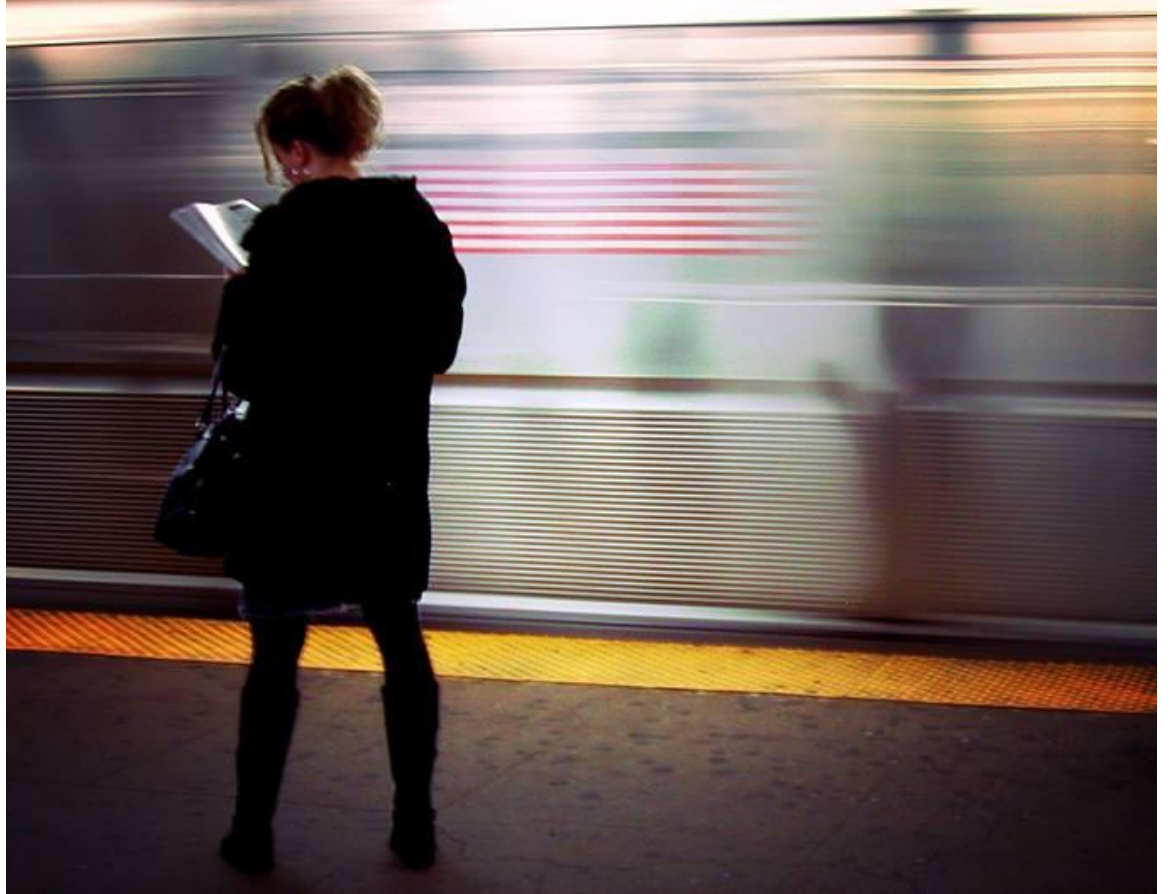

Fonte: Riza (2006).

\section{Considerações finais}

O percurso analítico aqui trilhado, ao somar-se com o conjunto de imagens que apresentamos, traz em seu bojo uma certeza: a conquista feminina das práticas de leitura se dá no interior de uma tensão sempre constante entre coerção e liberdade. Contudo, olhando retrospectivamente, é possível observar importantes transformações históricas, sociais e culturais que apontam, no contexto atual, para um equilíbrio das forças moduladoras desses dois polos. Se no período final da Idade Média as mulheres eram tratadas como uma "propriedade" masculina, sendo, por isso, mantidas à margem da vida comunal e podendo ler somente o que era considerado "bom" por seus pais e maridos, cinco séculos depois, logo em seguida à revolução industrial, elas foram postas a devanear sobre seus livros, cultivando suas próprias fantasias e, por consequência, fomentando as fantasias dos espectadores de suas belas e insinuantes imagens.

Desde a segunda metade do século XX, as representações visuais de mulheres leitoras nas mais diversas situações e cenários, exibem moças e senhoras autônomas com ações de leitura incorporadas naturalmente aos seus universos cotidianos. Destarte, assistimos, hoje, 
à conformação de um vigoroso mercado dedicado a satisfazer as necessidades específicas dessas consumidoras.

É claro que as distintas figurações acionadas em cada um dos três períodos não se portam apenas como narrativa de um lento, mas progressivo processo de emancipação, mais que isso, essas imagens deixam claro que, como bem observou Michelle Perrot (1995, p.9), “[...] as mulheres têm uma história e não são apenas destinadas à reprodução, que elas são agentes históricos que possuem uma historicidade relativa às ações cotidianas". Sendo assim, não se pode deixar de observar que as representações visuais de mulheres leitoras em todos os tempos e lugares - evidenciam-se como importantes e preciosos dispositivos interpretativos, reveladores de jogos de poderes. Ou seja, mais que belos exemplares de movimentos artísticos ou exercícios criativos, as pinturas, esculturas e fotografias aqui expostas retratam normas e juízos de valor notáveis, que dizem demasiado das condições de vida de um imenso universo de leitoras posicionadas no extra-campo dessas imagens.

Nesses termos, olhar para os índices de significação instaurados e difundidos pelas representações visuais da mulher leitora permitiu-nos apreender e assinalar alguns referentes simbólicos e visões de mundo que pautam tanto as demarcações sociais dos lugares que elas ocupam ou poderiam ocupar quanto sua inserção no universo geral das práticas de leitura. Com isso, as reflexões aqui desenvolvidas nos levam a reafirmar não apenas a relevância deste precioso objeto de pesquisa, mas também a enorme potência dessas imagens. Elas nos fazem conjeturar - e concluir, enfim - sobre as transmutações desta prática cultural e como esse processo aponta para uma luta emancipadora que não se iniciou há décadas ou séculos passados, mas que é retomada a cada dia, a cada hora, em todos os cantos do mundo. Eis porque afirmamos, em certo ponto do presente texto, que ler é experimentar possíveis.

\section{Referências}

ABADIA de Fontevraud. Escultura fúnebre para a tumba de Leonor de Aquitania. França. Disponível em: <http://vidasfamosas.com/2010/05/21/leonor-de-aquitania-corazon-deleona/>. Acesso em: 19 out. 2015.

ALBERT, Micah. At the Dandora dump. 2013. 1 fotografia, color. Foto apresentada na mostra World Press Photo 2013, organizada pela Caixa Cultural Brasília. Disponível em: <http://www.micahalbert.com/buried-in-dandora/k6i98xdwvb0dc33igxi7r891cdzpew>. Acesso em: 19 out. 2015. 
ALLORI, Alessandro. Madalena Penitente. 1602. 1 original de arte. Disponível em: $<$ http://www.atlantedellarteitaliana.it/index.php?artwork=1420\&lang=english $>$. Acesso em: 19 out. 2015.

BEHMER, Hermann Fenner. Leito ávido. [1906]. Disponível em: $<$ http://4.bp.blogspot.com/CHomiEKiYZQ/UUoIzermEmI/AAAAAAAAil8/DJSVa3AC1T0/s1600/FennerBehmer,+Hermann+(1866\%E2\%80\%931913)+Der+B\%C3\%BCcherworm,+ca.+1910.jpg>. Acesso em: 19 out. 2015.

BENNER, Emmanuel. Maria Madalena no deserto. 1886. 1 original de arte. Disponível em: http://almacattleya.blogspot.com.br/2011/09/perche-si-legge.html. Acessado em: $19 / 10 / 2015$

BERNÁRDEZ, Asunción. Pintando la lectura: mujeres, libros y representación en el siglo de oro. Edad de oro, v. 26, p. 67-89, 2007. Disponível em:

<http://eprints.ucm.es/10411/1/Pintando_la_lectura_Edad_de_Oro.pdf >. Acesso em: 19 out. 2015.

BLONCOURT, Gérald. Ônibus biblioteca na cidade de Levallois Perret, França. [1960]. Fotografia, preto e branco. Disponível em: <http://books0977.tumblr.com/image/115819490262>. Acesso em: 19 out. 2015.

BOLLMANN, Stefan. Mulheres que lêem são perigosas. Lisboa: Quetzal Editores, 2007.

BOTERO, Fernando. Mulher lendo. [2002]. Disponível em:

<http://arvoreestante.blogspot.com.br/search/label/BOTER0\%20\%28Fernando\%29>. Acessado em: 19/10/2015.

BROWN, Delia. Lendo na sala vermelha 2. [2006]. Disponível em: <http://www.deliabrown.net/Delia_Brown/Images/Pages/Forsaken_Lover.html\#1>. Acessado em: 19 out. 2015.

BURKE, Peter. Pintores como historiadores na Europa do século 19. In: MARTINS, José de Souza; ECKERT, Cornelia; NOVAES, Sylvia Caiuby (Org.). 0 imaginário e o poético nas ciências sociais. Bauru: Edusc, 2005, p.15-32.

CASA NOVA, Vera. Tal imagem, qual texto? Ou tal texto, qual imagem?. In: MARTINS, Aracy Alves et al. Livros e telas. Belo Horizonte: UFMG, 2011, p.144-148.

CAVALLO, Guglielmo; CHARTIER, Roger (Orgs.). História da leitura no mundo ocidental. São Paulo: Ática, 2002, 2 v. (Múltiplas escritas, v. 2).

CERTEAU, Michel de. A invenção do cotidiano: artes de fazer. Petrópolis: Vozes, 1994.

CHARTIER, Anne-Marie; HÉBRARD, Jean. A invenção do cotidiano: uma leitura, usos. Projeto História, São Paulo, v. 17, p. 29-44, nov. 1998. 
CHARTIER, Roger. Mulheres de papel: prefácio. In: LACERDA, Lilian de. Álbum de leitura: memórias de vida, histórias de leitoras. São Paulo: Unesp, 2003, p. 17-24.

CHARTIER, Roger. Os desafios da escrita. São Paulo: UNESP, 2002.

CLEVE, Joos van. Anunciação. 1525. 1 original de arte. Disponível em: <http://pt.wahooart.com/@@/8Y375J-Joos-Van-Cleve-o-anuncia\%C3\%A7\%C3\%A3o>. Acesso em: 19 out. 2015.

COMPAGNON, Antoine. Literatura para quê? Belo Horizonte: UFMG, 2009.

DALARUN, Jacques. 0 olhar de clérigos. In: DUBY, Georges; PERROT, Michelle. História das mulheres no Ocidente: a Idade Média. Porto: Edições Afrontamento, 1990. p.29-63.

DIRCEY. Frank. The Novel: a lady in a garden reading a book. [1880-1888]. Disponível em: <https://anemalon.files.wordpress.com/2012/08/r2bfrank2bdicey2b25281838188825292bthe2bnovel252c2ba2blady2bin2ba2bgarden2breading2ba2bbook2b252822529.jpg>. Acesso em: 19 out. 2015.

ESTACHON, Louis Antoine. Leitura no parque. [1850]. Disponível em: $<$ https://upload.wikimedia.org/wikipedia/commons/6/6a/Louis_Antoine_Estachon_Lesen de_in_Parklandschaft_1858.jpg >. Acesso em: 19 out. 2015.

EYCK, Jan van. Maria com o menino que lê. 1433. Disponível em: <http://pt.wahooart.com/@@/8XYBH2-Jan-Van-Eyck-o-\%60ince\%60-sal\%C3\%A3omadonna-(a-virgem-e-crian\%C3\%A7a-leitura>. Acesso em: 19 out. 2015.

FABRIANO, Antonio da. São Jerônimo no scriptorium. 1451. 1 original de arte. Disponível em: <http://lh3.ggpht.com/2T80a10l2KE/UV1f4jLz6rI/AAAAAAAAF7k/M6grqP_3CCI/s1600h/clip_image002\%25255B4\%25255D.jpg>. Acesso em: 19 out. 2015.

FRUGONI, Chiara. A mulher nas imagens, a mulher imaginada. In: DUBY, Georges; PERROT, Michelle. História das mulheres no Ocidente: a Idade Média. Porto: Edições Afrontamento, 1990, p.461-511.

GOULEMOT, Jean-Marie. Esses livros que se lêem com uma só mão: leitura e leitores de livros pornográficos no século XVIII. São Paulo: Discurso Editorial, 2000. (Clássicos e comentadores).

HASENCLEVER, Peter. A sentimental. [1847]. Disponível em: <https://rceliamendonca.files.wordpress.com/2012/06/johann-peter-hasenclever-18101853-the-sentimental.jpg>. Acesso em: 19 out. 2015.

HOPPER, Edward. Lobby de hotel. [1943]. Disponível em: <http://www.todocuadros.com/tienda/reproducciones-oleo/hopper/lobby-hotel>. Acessado em: 19 out. 2015. 
ISER, Wolfgang. 0 ato da leitura. Uma teoria do efeito estético. São Paulo: Editora 34, 1996, $2 \mathrm{v}$.

JAUSS, Hans Robert. Pour une esthetique de la recepcion. Paris: Gallimard, 1990.

LYONS, Martyn. Os novos leitores no século XIX: mulheres, crianças, operários. In: CAVALLO, Guglielmo; CHARTIER, Roger (Orgs.). História da leitura no mundo ocidental. São Paulo: Ática, 2002, v. 2, p. 165-202.

MANGUEL, Alberto. 0 espectador comum: a imagem como narrativa. In: Lendo imagem: uma história de amor e ódio. São Paulo: Companhia das Letras, 201, p.15-33.

MENESES, Ulpiano Bezerra de. Rumo a uma "história visual". In: MARTINS, José de Souza; ECKERT, Cornelia; NOVAES, Sylvia Caiuby (Org.). 0 imaginário e o poético nas ciências sociais. Bauru: Edusc, 2005, p.33-56.

METZKES, Harald. Mulheres cultas. [2001]. Disponível em: <http://matematicaold.unibocconi.it/donne2008/donneleggono01.jpg>. Acesso em: 19 out. 2015.

NIEMEYER, John Henry. Sonhadora. [1881]. Disponível em:

<http://www.artnet.com/artists/john-henry-niemeyer/wistful-Qz680g-zUQfNnJSrvpf5sQ2. Acesso em: 19 out. 2015.

PEPONNIER, Françoise. 0 universo feminino: espaços e objetos. In: DUBY, Georges; PERROT, Michelle. História das mulheres no Ocidente: a Idade Média. Porto: Edições Afrontamento, 1990, p.441-459.

PERROT, Michelle. Escrever uma história das mulheres: relato de uma experiência.

Cadernos pagu, v.4, p.9-28, 1995. (Dossiê: História das mulheres no Ocidente)..

PETIT, Michèle. A arte de ler: ou como resistir à adversidade. São Paulo: Editora 34, 2009.

PIGLIA, Ricardo. 0 último leitor. São Paulo: Companhia das Letras, 2006.

RICOEUR, Paul. Mundo do texto e mundo do leitor. In: Tempo e narrativa. Campinas: Papirus, 1997, p.273-314, v.3.

RIZA, Mo. Na plataforma lendo. [2006]. Fotografia, color. Disponível em: <http://p3.publico.pt/sites/default/files/livro_flickr.jpg>. Acesso em: 19 out. 2015.

ROUSSEL, Theodore. Moça que lê. [1887]. Disponível em:

$<$ https://elianaatihe.files.wordpress.com/2013/01/leitora-nua.jpg>. Acesso em: 19 out. 2015.

SOLMSSEN, Kurt. Leitura de verão. [2003]. Disponível em:

<http://kurtsolmssen.net/images/2003sum.jpg>. Acessado em: 22 out. 2015. 
TIEPOLO, Giambattista. Educação da virgem. 1732. Disponível em: $<$ http://www.niceartgallery.com/pt/Giovanni-Battista-Tiepolo/The-Education-of-theVirgin-Mary-1732.html>. Acesso em: 19 out. 2015.

WATT, Ian. A ascensão do romance: estudos sobre Defoe, Richardson e Fielding. São Paulo: Companhia das Letras, 1990.

WEYDEN, Rogier van der. Tríptico da Anunciação. [1434-1440]. 1 original de arte. Disponível em: <http://virusdaarte.net/wpcontent/uploads/2014/11/pres\%C3\%A9p1.png>. Acesso em: 19 out. 2015. 19/10/2015.

WILKIE, David. Reading the Will. [1820]. Disponível em: <http://www.wikiart.org/en/david-wilkie/reading-the-will-1821>. Acesso em: 19 out. 2015.

WOOLF, Virginia. Um teto todo seu. Rio de Janeiro: Nova Fronteira, 1985.

\title{
Visual representations of the reading woman: notes on the mutations of a cultural practice
}

\begin{abstract}
The work presents partial results of an investigation seeking to apprehend the symbolic-representational place occupied/destined to women on what concerns the history of reading. Therefore, it adopts as empirical universe the figurations and visual experiences conceived by plastic artists and photographers in the general context of the history of art. Taking as its empirical object an extremely vast group of pictorial and photographic works, the study analyses three specific moments in which the reading gestures performed by women in their contact with press objects configure themselves according to boards of meaning deeply rooted in the cultural sphere, that is: the zealous mother who transmits to her children, while reading, the precepts and norms anchoring religious and communal life in the Middle Ages; the dreaming young ladies of the romantic period who made of reading, both public and private, a resource of individual and emancipating self-formation; and, at last, reading as a common practice incorporated to everyday life of "modern" women, be they at home or at collective spaces, in moments of leisure or labor activities. By the end of this trajectory, one highlights the fact that reading is a cultural practice of apprehending and symbolizing the world whose gestures, activities, productions and representations take place, to a large extent, in different matrixes of signification that conform and inform social life.
\end{abstract}




\section{Keywords}

Reading. History of reading. Women's reading. Visual representation. Imagination. Press objects. Cultural practice.

Recebido em 11/09/2015

Aceito em 30/11/2015 